\title{
Čakanie na „našu“ Mohanty: Formovanie feministického diskurzu počas transformácie a jeho kritiky ${ }^{1}$
}

\author{
Waiting for "Our" Mohanty: The Formation of Feminist Discourse \\ During the Transition and Its Critiques
}

Zuzana Kepplová

\begin{abstract}
In this article, I follow the line of recent Czech feminist critique discussing the impact of transition ideologies on early post-socialist feminist theory in the Czech Republic (with ramifications for Central and Eastern Europe). Employing the approach of Kiossev and Buden, I further study the transition rhetoric employed in the works of early Czech and Slovak feminists. I argue that it was the set of rhetorical figures and modes of speech navigating their discourse which resulted in limitations on their political imagination. Furthermore, I frame this critique within the larger context of the institutionalization of feminist discourses in CEE to highlight possible power lines which structured the process of the domestication of feminist theories and gender analysis in the region. Finally, I propose that pursing analysis on the intersection of these two critical lines opens avenues for the renegotiation of possibilities that the category of gender may offer when cautiously informed by the post-socialist context which, by definition, questions the political coding of the feminist project.
\end{abstract}

KEY WORDS Early post-socialist feminism, feminism East-West, transition, hegemony, ideology, feminist knowledge production, post-socialism

Aby sme pochopili, prečo sa v Česku (a z časti aj na Slovensku) udomácnila v 90. rokoch určitá verzia feminizmu, nestačí hovorit’ o sebakolonizačných tendenciách tzv. Východných feministiek (Kodíčková 2002). Taktiež nestačí vysvetlit', prečo feministky svojimi diskusiami tvrdošijne upevňovali kategórie Východ-Západ² zdedené zo studenej vojny miesto toho, aby ich podrobili kritike a dekonštruovali (Kampichler 2012).

Sociální studia. Katedra sociologie FSS MU, 1/2014. S. 11-39. ISSN 1214-813X.

1 Za vzácne rozhovory nad skoršími verziami tohto článku d’akujem Martine Kampichler. Taktiež chcem vyjadrit' vd’aku recenzentkám/recenzentom, ktoré/í svojimi pripomienkami výrazne obohatili a usmernili tento text. Zároveň si uvedomujem, že článok si uchováva určité črty eseje a viaceré kritické vyhlásenia nie sú dostatočne podložené a rozvedené. Dúfam totiž, že tento článok je úvodom do d’alšieho skúmania a diskutovania naznačených tém.

2 Písaním vel'kých písmen chcem nadviazat' na kritiku, ktorá poukazuje nato, že tieto kategórie sú diskurzívne vytvárané a majú sa k sebe v hierarchickom vzt’ahu: Východ/Západ, Východné ženy / Západné ženy, Východné feministky / Západné feministky. 
V tomto článku jednak pokračujem v línii súčasnej českej feministickej kritiky (Kodíčková 2002; Kampichler 2012) osvetl'ujúcej, prečo sa rané postsocialistické feministky môžu javit' ako málo kritické a odvážne v spore o formuláciu ich vzt’ahu k tzv. Západnému feminizmu. Následne upozorn̆ujem na podnetnú líniu skúmania, ktorá sa zameriava na mapovanie pokladania infraštruktúry postsocialistického feminizmu v podobe inštitucionalizácie rodových/genderových štúdií a vzniku mimovládnych organizácií presadzujúcich feminizmom inšpirovanú agendu (Ghodsee 2004; Zimermann 2007; Cerwonka 2009; Cîrstocea 2009). Ked' sa tieto dve kritické línie pretnú, vyplnia biele miesto, ktoré vnímam v súčasnom pohl'ade na situáciu rodových/genderových štúdíi a feministickej teórie v Česku a na Slovensku.

\section{Klasický problém záberu diskusie: štruktúra, alebo "agency“}

V článku sa chcem pokúsit' rozvinút' niektoré podnetné línie skúmajúce situovanost' feminizmu do rámca transformačných ideológií, ktoré Kodíčková a Kampichler ponúkli vo svojich štúdiách. Zároveň umiestnim ich kritickú ponuku do širšieho diskurzu prepojenia moci a poznania $\mathrm{v}$ kontexte inštitucionalizácie rodových/genderových štúdií $\mathrm{v}$ regióne $\mathrm{CEE}^{3}$ (Ghodsee 2004; Zimermann 2007; Cerwonka 2009; Cîrstocea 2009).

Vymenované feministické kritičky nahliadali na proces inštitucionalizácie rodových/ genderových štúdií v súvislosti s projektom vytvárania občianskej spoločnosti, demokratizácie, reformy vzdelávania a nezanedbatel'ného začleňovania krajín CEE do priestoru trhovej ekonomiky. Z ich argumentácie vyplýva, že rodová/genderová agenda bola pomocným nástrojom pretvárania post-socialistického priestoru a jeho podrad'ovania pod nové mocenské celky, diskurzívnou okupáciou. Zároveň sa však v ich kritikách vytrácajú zo záberu spôsoby, ktorými lokálne akademičky aj aktivistky vyjednávali svoju pozíciu v rámci toho, čo častokrát pôsobí ako hegemónny diskurz zabalený do obalu modernizácie, reformy, pokroku a zvýšenia rozsahu demokracie, v ktorom majú lokálne hlasy málo vplyvu na formuláciu podmienok a samotného programu, stávajú sa len vykonávatel'mi/kami.

Problémom skúmania feministických aktivít vo vel'kých celkoch je to, že sa zmazávajú vzácne nuansy a rozdiely. Watson, Ghodsee, Zimermann, Cerwonka a Cîrstocea síce ponúkajú kritický pohl'ad na ekonomicko-politické tlaky, ktoré formovali možnosti lokálneho feminizmu. Zároveň však strácajú zo zretel’a motivácie raných feministiek, ktoré udávali smer diskurzívnym tokom a strategizovali, čiže neboli len väzeňkyňami vo vleku udalostí nadživotnej vel'kosti ako transformácia, neoimperiálne záujmy či diskurzívna kolonizácia primknutá k zavádzaniu trhového hospodárstva.

Získavanie konsenzu (dôležitého pre akúkol'vek hegemóniu) totiž nebolo a nie je vôbec l'ahké. V tomto bode podávajú horeuvedené štúdie neúplnú správu, ked’že z ich podania môže vzniknút' dojem, že išlo o vít'azné t’aženie. Watson (2000) a Cirstocea (2009) formulovali problém s presadzovaním rodovej/genderovej agendy opatrnejšie ako tzv.

Zaužívaná skratka CEE označuje strednú, juhovýchodnú a východnú Európu. Implicitne tu spadajú postsocialistické štáty (nejde teda o striktne geografické hl'adisko, ale o označenie berúce do úvahy rozdelenie sveta pred rokom 1989). 
antifeministický paradox. Jednak totiž v porevolučných postsocialistických spoločnostiach naprieč krajinami rezonovali nepriaznivé nálady voči feminizmu (alebo voči tomu, čo sa za feminizmus pokladalo), no na strane druhej sa pomerne rýchlo (aj ked' nie vždy l'ahko) etablovali rozličné inštitúcie, ktoré produkovali feministické poznanie a reprodukovali rodovú/genderovú agendu.

Neznamená to, že sa máme priklonit’ k nekritickej oslave dosiahnutých zmien a akcieschopnosti jednotlivých teoretičiek aj aktivistiek. Zaužíval sa totiž reflex pokladat' štruktúry za „zlé“ a akcieschopnost' (agency) za „dobrú“. Menej pozornosti sa venovalo prešetrovaniu tzv. „,agency“ čiže akejsi miere slobody v rámci daných štruktúr. V rozpore s týmto zlozvykom napríklad Abu-Lughod (1990) vynikajúco ukázala, ako gestá rezistencie zároveň napájajú hegemónne diskurzy, ako $\mathrm{v}$ určitých kontextoch získavanie osobného priestoru, sebaoslobodzovanie, sebavyjadrenie zapadá do projektu kolonizácie identít a ich začleňovanie do špecifickej vízie modernity, logiky trhu či štruktúr štátnej moci. Abu-Lughod obracia foucaultiánsku rovnicu moci a tvrdí, že by sme mali venovat' kritickú (a podozrievavú) pozornost' známkam odporu, pretože tak možno diagnostikovat' meniace sa mocenské mapy. Zatial'čo skorý Foucault tvrdí, kde je moc, je aj odpor, Abu-Lughod (1990: 42) sa prikláňa $\mathrm{k}$ jeho neskoršej reformulácii, že tam, kde sú prítomné známky rezistencie, možno najlepšie vystopovat' pôsobenie moci.

Nájst' správne merítko záberu diskusie bez toho, aby sme prepadli oslavovaniu ,agency“ či démonizovaniu štruktúr, je zložitá úloha. Preto si v tomto texte dávam za ciel' najmä zblížit' hladisko vel'kých mocenských presunov (Watson, Ghodsee, Zimermann, Cerwonka, Cîrstocea) s kritikou transformačných ideológií prítomných $\mathrm{v}$ prácach autoriek, ktoré analyzujú Kodíčková a Kampichler. Verím, že takto možno lepšie postihnút' nuansy aj neurčitosti, ktorých sa neradno zbavovat' $\mathrm{v}$ prospech jasných odpovedí.

\section{Paradox sebareflexie: hryzenie do vlastného chvosta?}

Štúdie Ghodsee, Zimermann, Cerwonky a Cîrstocea jednak zasadzujú udomácnenie inštitucionalizovaného feminizmu a rodovej/genderovej analýzy v regióne CEE do dôležitých kontextov a historických situácií. Súčasne tiež praktizujú formu sebareflexie, ktorá je práve doménou kritických disciplín, ako sú aj rodové/genderové štúdie. Výsledkom je paradoxná situácia zahryzávania sa do vlastného chvosta. Uvedomujem si teda, že niektoré uvedené kritiky zdanlivo napádajú legitimitu mojej vlastnej disciplíny.

Za zvýšenú citlivost' na otázky reprodukcie moci cez štruktúry poznania vd’ačíme jednak bourdieuovsko-foucaultiánsko-saidovskej kritike, ktoré $\mathrm{v}$ nemalej miere rozvinuli aj feministické teoretičky ako Harding, Haraway, Mohanty alebo Spivak. A síce sa na to častokrát v panteóne kritickej teórie zabúda, tieto východiská predchádzali aj odvážne komentáre k poriadku „moderného“ sveta v prácach od Wollestonecraft, Woolf, Kollontai až k dnes málo populárnym radikálkam ako Millet, Firestone či Greer.

Feministické teórie preto významne prispeli ku kritike ustanovovania mocenských hierarchí, zneviditel'ňovania týchto štruktúr a ich legitimizácie ako „prirodzeného“ poriadku sveta. Navyše tiež vypracovali dôležitú metodiku sebareflexie vyplývajúcu z náhl’adov na formovanie poznania, ktoré spätne upevňuje/podrýva mocenské štruktúry. Hypersenzitivita 
na reprodukciu mocenských režimov a štruktúr útlaku sa častokrát obracia proti tým disciplínam, ktoré dôsledne na tieto problémy upozorňujú. ${ }^{4}$

Už rané feministky v priestore CEE (napríklad Drakulić 1992; Šmejkalová 1997; Slavova 2006; Blagojević 2006) sa snažili postihnút', ako sa línie mocenských hierarchií formujú aj prostredníctvom kategórií feministického poznávania. Problematickým bodom ich argumentácie však zostáva, že sa identifikovali s nálepkou tzv. Východných feministiek tlmočiacich hlasy tzv. Východných žien. Ako upozorn̆uje Kampichler (2012: 12-13), takáto stratégia zároveň identifikované hierarchie reprodukuje a legitimizuje. Autorky vychádzajú z užitočnej snahy formulovat' teóriu, ktorá lepšie zodpovedá potrebám regiónu než „importovaný، feminizmus, - pokúšajú sa o postihnutie lokálnych špecifík, no zároveň pokračujú v exotizácii regiónu CEE a vytváraní identity Východu, ktorý je a priori iný než Západ a potrebuje špeciálnu dávku porozumenia a senzibility (zároveň sa tak samotné katapultujú do pozície expertiek, ktoré tieto odlišnosti postihnú a prípadne pomôžu odstránit').

Kým Východ podlieha analýze - či už s nádychom ospravedlňovania alebo posilňovania identity - Západ častokrát zostáva mimo problematizácie a zachováva si status normy, akoby išlo o reálne existujúce celky a nie previazané súbory vzt'ahov. A teda to, čo na prvý pohl'ad pôsobí ako emancipačná stratégia „hlasov z Východu“, zostáva podl'a Kampichler (2012: 11-12) ukotvené v logike rozdelenia sveta na Západ a Východ.

Kodíčková (2002) ešte dôraznejšie nástojí na symbolike rozvinutého-nerozvinutého sveta, ktorá riadila nielen feministické diskurzy, ale výrazne formovala (formuje?) dianie v našich krajinách. Túžbu po tzv. normálnosti ako dôležitej rétorickej figúre transformácie (transition) si všimol aj Kiossev (2008). V procese tzv. normalizácie pomerov je súčasnost' nahliadaná ako čakáreň na budúcnost’ a ako taká stráca relevanciu. Ďalej transformačné naratívy významne demýtizoval Buden (2013 [2009]), ked' napríklad poukázal nato, ako sa logika emancipácie - zbavenie sa nadvlády, sebaurčenie - mení a stáva sa majetkom západných poručníkov vyvádzajúcich svojich zverencov (alebo v tomto prípade zverenkyne) na svetlo poznania. V línii poukazovania na transformačné ideológie, ktoré podopierajú imaginárny Západ-Východ, pracujú aj feministické autorky ako Kodíčková a Kampichler.

\section{Prečo dnes skúmaf' udomácňovanie sa rodovej/genderovej analýzy u nás?}

Prečo je dôležité preskúmat' spôsoby, akými sa feministické diskurzy a rodová/genderová agenda zčasti primkýnali/primkýnajú k ideológiam a stratégiam transformácie? Nie je pozícia rodových/genderových štúdií (aj napriek argumentom horeuvedených autoriek o ich rýchlom udomácnení sa $\mathrm{v}$ regióne CEE) vel'mi krehká a ohrozitel’ná antifeministickými náladami v spoločnosti aj na akadémii? S ohl'adom na tieto námietky tvrdím, že sa treba zamerat' aj

4 Treba si preto uvedomit', že kritické poznámky by sa nemali jednostranne namierit' voči feministickým agendám. Napríklad liberálne či konzervatívne inštitúcie síce podliehajú kritike, no málokedy prichádza z vlastných radov. Naopak sa snažia zmazávat' stopy a etablovat' sa vo sfére ,pravdy“ a „objektivity“. Za túto opatrnú pripomienku vd’ačím rozhovoru s L’ubou Kobovou aj Martinou Kampichler. 
na to, ako sa určité agendy a postupy vyšmykávajú tým, ktorí/é praktizujú sebareflexiu, a sú unášané na účely upevňania hegemónie.

$\mathrm{V}$ posledných desat'ročiach môžeme pozorovat' podstatnú a vzrastajúcu tendenciu prepožičiavania si agendy rodu/genderu a práv LGBT l'udí ako vhodného nástroja, cez ktorý sa legitimizujú vojenské misie a tiež opatrenia obmedzujúce určité skupiny obyvatel'stva vnímané ako hrozba (Abu-Lughod 2002). Zároveň sa (uniformovaný a podstatne zjednodušený) rod/gender a otázka LGBT práv stali dôležitou rubrikou, cez ktorú sa vedú ostro rozdel'ujúce línie medzi novým (rozšíreným) Západom a novým (moslimským aj ortodoxným) Východom a tiež vnútri jednotlivých štátov, kde vydel’ujú „nemoderné“ komunity. ${ }^{5}$

Myslím si teda, že diskusie o podobách feminizmu u nás dnes nie sú témami na okraji, aké boli počas 90. rokov, ked' museli priaznivkyne nových myšlienok legitimizovat' svoje presvedčenie a oprávnenie zaoberat' sa rodom/genderom voči obvineniam z prenášania agendy z minulého režimu (Kepplová 2013) alebo voči „importu“ cudzích myšlienok (Šiklová 1997). Dnes síce antifeministické hlasy tiež znejú výčitkami, že „džendristickí experti“ (sic!) páchajú „sociálne inžinierstvo“ (Komárek 2012: 234), no z výčitky ideologickej perverzie sa stáva podstatnejšia kritika smerovania Západu, ktorý si rod/gender osvojil ako svoju civilizačnú značku.

Kým konzervatívni kritici ako Komárek (2013) sa ešte oháňajú kategóriou prirodzenosti a bijú na poplach na poli populačnej politiky (Komárek stavia do protikladu Západ na vyhynutie s nebezpečným, no ,prirodzenost'ou“ sa riadiacim, Východom), zo samotných feministických radov zaznieva ovel'a zaujímavejšia a provokatívnejšia kritika prešetrujúca, nakol'ko sa inovačné impulzy feministického hnutia a LGBT komunít stali (v kooptovanej verzii) motorom pre kapitalizmus uspôsobujúci sa na vyšší výkon a väčšiu flexibilitu v podmienkach postindustriálnych zmien (Fraser 2009 [úryvok v češtine v A2 23/2013]).

Chcem preto upriamit' pozornost' $\mathrm{k}$ záujmu o kontextuálnejšie vnímanie feministických teórií a rodovej/genderovej agendy. Kritická tradícia využívaná aj na poli rodových/genderových štúdií ponúka účinné nástroje sebareflexie - akési zrkadlo, v ktorom osoba dívajúca sa doňho vidí samú seba, ako sa díva do zrkadla. Zatial'čo nie je možné zbavit' sa mocenských hierarchií púhým odteoretizovaním, lepšie uchopenie vlastných východísk by mohlo napomôct' vnímaniu problematických diskurzov, s ktorými sa feminizmus a rodová/genderová analýza pretína a/alebo ich reprodukuje.

\section{K formulovaniu post-transformačného skúmania}

Ukotvenie feministických prístupov a rodovej/genderovej analýzy v transformačných ideológiach sa týka tak českého ako aj slovenského feministického prostredia. Obe prostredia vychádzajú z odlišných tradícií a upevňujú sa v nich iné tendencie. Na ploche tohto článku sa mi nepodarí dôsledne sa týmto odlišnostiam venovat', no dovolím si tvrdit', že rámcovanie

Ako ukázal košický Pochod za život a nedávne návrhy zmeny v slovenskej Ústave prisudzujúce status manželstva výlučne zväzku muža a ženy, častokrát tu nejde o menšinový diskurz, ale silné konzervatívne prúdy v slovenskej spoločnosti, ktoré odvádzajú politickú pozornost' od skutočných hrozieb rozdel'ujúcich túto spoločnost'. 
transformačnými ideológiami možno vnímat' $\mathrm{v}$ oboch týchto prostrediach. Ako naznačuje analýza vybraných textov u Kodíčkovej a zborníkov týkajúcich sa debaty Východ-Západ u Kampichler, určité závery možno rozšírit' aj na kontexty CEE. ${ }^{6}$

Ako uvádzajú autorky správy Gender Issues 2009, české feministické prostredie sa v priebehu 90. rokov a najmä v novom miléniu diverzifikovalo (pozri aj Nyklová 2013). Pre potreby tohto textu (vychádzajúceho z kritík Kodíčkovej a Kampichler) však môžeme hovorit' o akomsi hlavnom prúde, ktorý je v porovnaní so Slovenskom viac spoločenskovedne orientovaný (no nezanedbatel'né sú tiež impulzy z jazykových katedier). ${ }^{7}$ Tu sa opät žiada podrobnejšia štúdia stopujúca trasy „cestujúcich teórií“, ako to predznačila napríklad Šmejkalová (1997).

Kodíčková sa vo svojej štúdii sústredí na rané práce Hany Havelkovej a Jiřiny Šiklovej, kým Kampichler preostruje našu pozornost' na vyzývatel'ky feministických diskusií na trase Východ-Západ, a to hlavne v zborníku Gender Politics and Post-Communism. Kampichler teda ukazuje, že Havelková, Šiklová, ale aj iné autorky účastniace sa týchto diskusií naprieč CEE, následne pracovali v mantineloch prednastavených napríklad aj textami Nanette Funk, ktoré daný zborník rámcovali.

Obe autorky, Kodičková aj Kampichler, volajú po prekonaní bariér, ktoré z vel'kej časti ohradili územie následných diskusií a predmetov bádania. Pre Kodíčkovú je to najmä otázkou lepšej informovanosti o novších feministických teóriach a to hlavne tých, ktoré sa viac-menej

6 Zatial'čo v krajinách strednej Európy či Pobaltí rezonoval diskurz Vel'kého návratu, ktorý sa týka aj diskurzu feminizmu, Zimmerman (2007) ukazuje, že v štátoch bývalého Sovietskeho zväzu bola/je prítomnost' inštitúcií zastávajúcich rodovú/genderovú agendu a vychádzajúcich z feministických teórií problematickejšia. Markantným príkladom by mohla byt' „univerzita v exile“, ktorá sa musela v roku 2004 presunút' z Minsku, kde bola v roku 1992 založená, do litovského Vilniusu z dôvodu nevôle zo strany bieloruskej vlády. Univerzita je postavená na princípoch liberal arts college a ponúka tiež gender studies ako študijný program v rámci cultural studies. Ďalším príkladom by mohlo byt' vyostrenie prístupu ruských autorít, ked' boli odhlasované tzv. the gay propaganda law a blasphemy law reagujúce aj na aktivity mimovládnych organizácií (ako pochody hrdosti) a akcie feministickej punkovej skupiny Pussy Riot. Dalo by sa teda povedat', že práve cez problematiku rodu/genderu a LGBT vedú línie politického rozporu a tiež rozporu ohl'adom odlišných predstáv o modernite.

7 Podl'a Wöhrer (2005) slovenská postsocialistická feministická tradícia vyrastá z prepojenia ženského aktivizmu a písania (ešte z obdobia národného obrodenia). A teda slovenský postsocialistický feminizmus uprednostňoval literárne texty, teóriu a vizuálne umenie pred spoločenskovedným hl’adiskom - či už hovoríme o aktivitách mimovládnej organizácie Aspekt (od r. 1993), o Klube feministických filozofiek tvoriacich jadro neskoršieho Centra rodových štúdií na bratislavskej Univerzite Komenského (od r. 1992/2001) alebo tiež o pôsobení feministicky orientovaných umelkýň a teoretičiek na VŠVU a VŠMU (zároveň však nemožno zanedbat' práce sociologičiek zameriavajúcich sa na situáciu žien v postsocialistickej spoločnosti - vrátane aspektovskej série -, tiež mimovládne organizácie riešiace agendu násilia či materské centrá a práce historičiek/historikov reprezentované napr. v zborníku Na ceste k modernej žene). Ak teda hl'adáme určitý hlavný prúd, časopis Aspekt by mohol napomôct' ako reprezentant literárne-a-filozoficko-zvedavého feminizmu (na tejto trase pokračuje aj časopis Glosolália, ktorý vedie feministický literárny vedec Derek Rebro). 
úspešne dokázali vysporiadat's problematikou vlastnej situovanosti na periférii. Kodíčková symbolicky volá po „našej“ Mohanty, teda po výraznom hlase, ktorý bude schopný adekvátne formulovat' situáciu žien tzv. druhého sveta $v$ takej výraznej miere, ako to Chandra Talpade Mohanty dokázala pre ženy tzv. tretieho sveta. A to bez komplexov z odlišnosti, ktoré Kodíčková diagnostikuje ako vyplývajúce z podriadenia sa politickému projektu transformácie, ktorý žiada pomenovanie a odstránenie odlišností ako úspešný výsledok začlenenia sa Východu do Západu. V závere Kodíčková vyzýva na dôslednejšiu spoluprácu v rámci regiónu CEE - tejto požiadavke sa dá rozumiet' aj v náväznosti na stratégie odčlenenia sa od kolonizačných tendencií a rozvíjania vlastnej inakosti.

Kampichler je opatrnejšia v chápaní situácie raných postsocialistických feministiek. Vo svojej analýze d’alej využíva prístup Mohanty (1990, 2003), ktorá upozorňuje na vytváranie hierarchií v rámci univerzalizovanej kategórie žien - ženy emancipované a pomáhajúce vs. ženy utlačované a vyžadujúce intervenciu, pomoc s oslobodením - a d’alej tvrdí, že jednoduché uloženie rozličných hlasov do pestrej dúhy vzájomného porozumenia nerieši, ale naopak stabilizuje mocenské nerovnosti na poli feministického poznávania. Kampichler d’alej upozorňuje, že situácia nastavená na začiatku 90. rokov sa d’alej reprodukuje (napríklad v iných zborníkoch mapujúcich rod/gender v CEE), a to aj napriek zdanlivému vyprchaniu aktuálnosti debaty Východ-Západ.

Je to práve toto zneviditel'nenie alebo vrastenie „prirodzenosti“ daných hierarchií a rozdielností do podložia lokálnych feminizmov, ktoré treba nanovo prešetrit’ a problematizovat'. Takáto požiadavka je, myslím si, viac než relevantná a hodná d’alšieho záujmu. Na ploche tohto článku sa mi podarí otvorit’ len pár bodov možného post-transformačného skúmania.

\section{Možnosti a limity postsocialistických feminizmov}

Kodíčková a Kampichler analyzujú prácu s myšlienkovými východiskami a argumentačnými stratégiami na poli ranej postsocialistickej feministickej teórie, hodnotia prístupy, ktoré tieto feministky zaujali, a tiež ponúkajú akúsi opravenú verziu alebo cestu von zo slepých uličiek, ktoré identifikovali.

Kodíčková (2002) upozorňuje, že výsek feministickej teórie, ktorý české feministky adoptovali a d’alej spracovávali vo svojich kritikách, nezodpovedá vtedajším trendom vo feministickej teórií, ale je úzko naviazaný na liberálne východiská prvej aj druhej vlny feminizmu. Tie sa naopak stali terčom kritiky tzv. farebných žien, postkoloniálnej teórie a postštrukturalizmom inšpirovanej feministickej teórie. Kodíčková (2002: 71) zároveň tvrdí, že spomínané kritické prúdy $\mathrm{v}$ rámci feministickej teórie by mali $\mathrm{v}$ tom čase problém uchytit' sa $\mathrm{v}$ postsocialistickom priestore, pretože sú rámcované l'avicovými prístupmi, a tým by sa dostali do rozporu s výrazne antikomunistickými tónmi v spoločnosti.

Konkrétne možno zdôraznit', že viaceré stúpenkyne feminizmu v Česku a na Slovensku a nielen tam - sa regrútovali z antirežimových pozícií a/alebo nechávali nahlas zazniet', že sú na strane demokratizačného projektu a „modernizácie“ spoločnosti smerom k západným modelom. Uvedené kritické inšpirácie, ako dodáva Kodičková, by ich príslušnost' k tomuto projektu mohli naštrbit' a spochybnit' (či išlo o strategický výber, nedostatok informácií alebo 
ohraničenie obzorov družobnými Západnými feministkami zostáva u Kodíčkovej načrtnuté, no nedopovedané a táto otázka by si zaslúžila dôraznejšie preskúmanie).

Kampichler (2012: 5-7) si d’alej všíma, že ignorovanie novších smerov vo feministickej teórii zo strany niektorých vplyvných družobných feministiek malo za následok, že v regióne CEE sa na čas ustanovilo skúmanie rodu/genderu chápaného ako pohlavná diferencia. Ghodsee (2004: 730-732) si taktiež všíma špecifickú verziu feminizmu prenesenú do CEE a ponúka vysvetlenie, že zvýraznenie globálneho útlaku žien tu bolo ešte potvrdené predpokladom, že ženy z CEE budú paušálne obet’ami transformačných procesov a novým podmienkam sa budú horšie prispôsobovat'.

Z takejto logiky, ktorú Ghodsee, Watson aj Cirstocea označili za empiricky nepodloženú, vychádzali nároky družobných feministiek chránit’ a vzdelávat’ ženy z CEE. Takáto motivácia je zakódovaná aj v zborníkoch, ktoré Kampichler analyzuje a ktoré postupne vytvárali obraz tzv. Východných žien ako kategórie so špecifickými vlastnost’ami - zdôrazňovali sa ich odlišnosti od žien Západu, akoby tieto tvorili tiež určitú skupinu (zväčša na základe ich geopolitickej príslušnosti).

Napríklad už Drakulić uvádza, že v prípade programovej požiadavky písat' o ženách z východnej Európy ide o značne problematickú kategóriu: „Jedná sa tu o približne 70 miliónov žien žijúcich $\mathrm{v}$ rozličných oblastiach a kultúrach, hovoriacich rozličnými jazykmi a predsa zredukovaných na spoločného menovatel'a - systém, v ktorom žili“" (Drakulić 1992: 123 [preklad Z. K.]). Nejasnost' v pojmovom ohraničení je v centre teoretických debát medzi tzv. Východom a Západom. Ako si správne všimla Kampichler (2012: 11-12), ide tu totiž o podradenie feministických debát vyjednávaniu geopolitických hraníc a mocenských hierarchí́.

Rané teoretičky feminizmu d’alej vystupovali pod priradenou nálepkou a argumentovali v dialógu so Západnými feministkami z pozície Východu. Samozrejme sa dá takémuto postupu rozumiet' ako stratégii vychádzajúcej z reálnej potreby vysvetlit' pocit'ované a pozorované nezhody ponúkanej teórie s praxou a skúsenost’ou.

Kodíčková aj Kampichler upozorňujú na miesta výraznej zhody raných postsocialistických feministiek so staršími argumentami tzv. iných hlasov feminizmu (napríklad Havelková 1996, 1997 v Kodíčková 2002: 72; Havelková 1993 v Kampichler 2012: 10). Tzv. iné hlasy opakovane upozorňovali, že predpoklady hlavnoprúdovej feministickej teórie sa zakladajú na skúsenosti úzkej skupiny žien - bielych heterosexuálnych strednostavovských (zväčša) Američaniek - a teda výsledná analýza a emancipačné postupy neodrážajú situáciu iných žien (čo však neznamená, že mnohé tieto ženy nechceli formulovat' svoje požiadavky a pokračovat' tak vo feministickom projekte demaskovania a nápravy špecificky historicky a kultúrne podmienených foriem útlaku a exploitácie).

Niektoré rané postsocialistické feministky však rozostavovali pojem inakosti tzv. Východných žien len okolo ich historickej skúsenosti s predchádzajúcim režimom bez vnímania d'alších odlišností (naopak si však všímali a nástojili na spojitostiach s mužmi na základe zdiel'anej politickej skúsenosti, ako upozornila aj Wagnerová 1999: 81-83). Neskôr ukážem, že pre mnohé tieto autorky bola typická snaha vysvetlit' odlišnosti zapríčinené politickou „perverziou“ a nasmerovat' ich na cestu odklínania „skutočnej“ (nedeformovanej) ženskosti, ktorá sa tiež mala aktívne podiel'at' na výstavbe nového poriadku. 
Záujem (aj ked' negatívny) o skúsenost' so štátnym socializmom postavil politickú podmienenost' rozličných emancipačných ciest na čas do centra analýzy (najmä v slovenskom prípade však išlo o odsúdenie a hlavne odsunutie minulosti). Socialistická emancipácia bola z vel'kej časti vylúčená zo zorného pol'a a d’alej neriešená. Napríklad Cviková a Juráňová (2009b: 79) rekapitulujú pre správu Gender Issues 2009, že „slovenské autorky sa zvykli obzerat' za minulým režimom iba vtedy, ked' ich k tomu motivovali ich západné kolegyne, a to hlavne v prvých rokoch po 1989-om“. Následne bol socialistický emancipačný program - bez snahy o periodizáciu či hlbšie prešetrenie - odsunutý za okraj záujmu ako nefunkčný projekt (Kiczková a Farkašová 1993) či opakovane odmietaný ako ,povinn[ý], jednotn[ý] a nereflektovan[ý]““ (Cviková a Juráňová 2009a: 17).

V českom prostredí upozorňovali na vnímanie nuáns rodových/genderových poriadkov v socialistickom Československu hlavne emigrantky ako Wagnerová, Heitlinger či Šmausová, no náznaky porovnávacej perspektívy nechýbali ani v raných textoch spomínaných autoriek Šiklovej, Havelkovej či tiež Šmejkalovej, ktoré prešetrovali základné kamene „importovaných“ feministických teórií. ${ }^{8}$ Avšak napríklad v Šmejkalovej výhrade voči základnej premise druhej vlny feminizmu - osobné je politické (ak takýto výrok nebol obsiahnutý už v práci socialistickej feministky Kollontai) - zaznievajú tóny transformačnej ideológie, ked' Šmejkalová argumentuje vytúženou nedotknutel'nost'ou súkromia, privátneho priestoru. Nemožno dnes nevnímat’ techniky moci obsiahnuté v komunikačných technológiách, monitorovaní verejného priestoru či sprísňovaní prehliadok pri leteckej doprave a t’ažko predpokladat', že sa spájajú len s posledným desat'ročím. Ideál neprítomnosti kontroly a nedotknutel'nosti súkromia sa tak v spätnom zrkadle mení na prekonanú ideologickú floskulu.

Vo výsledku tam, kde mohla vzniknút’ ostrá kritika hegemónie Západného feminizmu (ako sa opakovane dialo z pozícií tzv. farebných žien a postkoloniálnej teórie), sa podl'a Kodíčkovej a Kampichler ponúka defenzívne a submisívne stanovisko poukazujúce na prijatie hegemónie Západných feministiek, ich prevahy na poli tvorby a spravovania poznania.

Pre Kodíčkovú aj Kampichler je dôležité ukázat', ako sa prenos (limitovanej) feministickej teórie, určenie kategórií diskusie a následná akceptácia špecifickosti tzv. Východných žien stali nástrojom mocenskej prevahy tzv. Západných feministiek na poli poznania. Obe kritičky si však uvedomovali a pokúsili sa objasnit', prečo sa naznačované kritické impulzy nemohli rozvinút' do podoby svojbytnej kritickej línie, ktorá by hegemóniu tzv. Západného feminizmu podryla. Snahy raných feministiek totiž ohraničovalo včlenenie do politickej predstavy, v rámci ktorej uznávali symbolickú aj faktickú hegemóniu Západu a viac alebo menej výrazne sa hlásili k projektu odstránenia identifikovaných odlišností.

Obe autorky (Kodíčková a Kampichler) sa zaoberajú vyjednávaním pozícií na poli teórie a nechávajú materiálne štruktúry feminizmu stranou. Cerwonka (2009) upozorňuje, aby sme preostrili z roviny ideí a všímali si dianie na úrovni infraštruktúry, ktorá určuje, čo bolo/je na poli postsocialistického feminizmu vôbec možné, vykonatel'né, myslitel'né. V d'alšej línií

Konzistentnejšia práca sa však vynára až v poslednom čase (napr. Havelková a Oates-Indruchová 2014). 
teda nasledujem autorky, ktoré tvrdia, že primárne treba pochopit’ politickú ekonómiu postsocialistického feminizmu, aby sme porozumeli témam a tendenciám, ktoré ho charakterizujú (Ghodsee 2004; Zimermann 2007; Cerwonka 2009; Cîrstocea 2009).

Vo svojich štúdiách sledujú vznik sietí mimovládnych organizácií, privátnych univerzít s agendou podpory utvárania občianskej spoločnosti, reformy v rámci harmonizácie európskeho systému vzdelávania, finančné toky regulujúce, aká agenda sa bude riešit', atd'. Súhrnne by sa dalo povedat', že tieto autorky napriek rozdielnostiam spája snaha vidiet' politiky rodových/genderových štúdií a „udomácnené“ feministické teórie v súvise s transformačnými procesmi vrátane následnej europeizácie aj rastúceho vplyvu anglo-americkej akademickej tradície.

\section{Problémy s prístupom ku zdrojom a prekódovaním akademického habitusu}

Podl'a Kodíčkovej (2002: 72) tzv. Východné feministky častokrát vynachádzali koleso, ked’ sa „brán[ili] proti homogenizaci, arogantní dezinterpretaci lokálních jevů, dekontextualizaci a podobně“. Ako som už naznačila, ich kritika sa v mnohých bodoch stretávala $\mathrm{s}$ tou pochádzajúcou od tzv. iných hlasov feminizmu (ale tiež s teóriami stanoviska ${ }^{9}$ ). Prenesené neduhy v teoretických prístupoch k regiónu CEE pomenovala už Šmejkalová, ked' napísala:

Mnohé feministické práce, které v jiném kontextu často rády stavějí na obdiv své inovační přístupy, tak de facto opakovaly všechny znaky studenoválečné [tzv.] sovětologie: nedostatek důkladné znalosti místního kontextu, slabé jazykové vybavení a povrchní zovšeobecňující závěry odvozené od modelu společnosti, v níž autorky a autoři těchto textů vyrostli. (Šmejkalová 1997: 16)

Kodíčková (2002: 75) sa vo svojej kritike na rozdiel od Šiklovej aj Kampichler zameriava na domáce autorky a poznamenáva, že na príčine boli problémy prístupu k novšej teórii, ked’že autorky zostávali znevýhodnené svojou materiálnou situáciou.

Podobne Cerwonka reprodukuje hlasy z rozličných akademických prostredí v rámci CEE vyjadrujúce, že hegemónia angloamerického akademického okruhu odsúva teoretičky z iných krajín za okraj. Byt’ na periférii ich z viacerých aspektov stojí viac - či už ide o vynaložené úsilie pri zapájaní sa do diskusie v inom ako materinskom jazyku, snahu o prienik do rešpektovaných časopisov, cestovanie na vzdialené konferencie, získanie prostriedkov na mobilitu a výskum, prístup k plateným databázam s článkami z karentovaných časopisov a podobne (Cerwonka 2009: 725-726). Cerwonka tu presúva pozornost' z prejednávania teoretických postojov - snáh o formulovanie teórie z Východu, svojbytnej kritiky a sebavedomého prešetrenia preneseného tzv. Západnému feminizmu - na úroveň materiálnych nerovností.

Cerwonkinu kritiku možno d'alej rozšírit', ked' si uvedomíme, že aj ked’/keby rané feministky tieto úskalia prekonali, stále tu bol problém akéhosi akademického habitusu. Aby som vyjadrila, čo mám na mysli, pomôžem si anekdotou. Spomínam si na konferenciu, na ktorej 
vystúpili viaceré feministky z tzv. Východu a Západu. Tieto kategórie tu neoznačujú geografickú príslušnost', ale schopnost' používat' akademický diskurz angloamerickej tradície v spôsobe zavedenom $\mathrm{v}$ gender studies a iných kritických disciplínach a sprevádzanom tiež príslušnou persónou. V kuloároch som zachytila znudený tón, ktorým akademičky z prestížnych inštitúcií, na ktorých sa pestujú gender studies, hodnotili „úbohú organizáciu“ podujatia a „nemožné príspevky“, z ktorých iba jediná prezentujúca ,actually made a point“. Prekvapili ma úzko nastavené očakávania akademičiek, ktoré vedia brilantne teoretizovat’ inakost', ak sa zjavuje v podobe ,rasy“ či „orientácie“, avšak nedokážu dekódovat' a pochopit’ inakost' akademického (ale aj spoločensko-kultúrneho) habitusu.

Obyčajne takáto anekdota spadá do oblasti kuloárových poznámok, no v rámci kritiky utvárania akademického habitusu si dovolím použit' ju ako dôkazový materiál. Tvrdím totiž, že aj gender studies, podobne ako iné disciplíny, produkuje určitý register prijatel'ných persón (nie je to prekvapivé zistenie). Toto je snád' najviac viditel'né pri účasti na konferenciách, kde sú kontúry očakávaného (osobného aj akademického) štýlu zjavnejšie. Ked’že som sa vo svojej dizertačnej práci zaoberala výskumom subkultúr, vypestovala som si zvýšenú citlivost' na štylizáciu a utváranie dojmu, no zároveň vnímam, ako sa performancia prepája s určitými pravidlami, ktoré dané prostredie utvárajú.

Jednak musí samotný text spĺn̆at' zavedené akademické náležitosti (sem spadá napríklad okruh zdrojov, ktoré možno citovat', aby príspevok získal určitú relevanciu v intenciách zdiel'aného poznania charakteristického pre disciplínu). Tiež jeho predvedenie orálnou formou by malo spĺn̆at’ očakávania (od správneho umiestnenia vtipu k dostatočnej miere radikálneho tónu). Performatívna úloha však nekončí prezentáciou, ale pokračuje za stolom v reštaurácii alebo počas obligátnej coffee break. Môže sa to zdat' triviálne, no aj takéto detaily hrajú podstatnú úlohu a tzv. Východné feministky sa museli naučit’ nové pravidlá hry, nové spôsoby bytia v akademickej koži.

Možno sa však predsa len pýtat', prečo napriek podobnosti v argumentácii s tzv. inými feministickými hlasmi nevyprodukovalo toto prostredie českú, slovenskú či rumunskú Mohanty alebo Spivak?

Pozrime sa len vel'mi letmo na kontext práce oboch spomínaných autoriek, ktoré tu slúžia ako zástupné mená symbolizujúce hviezdy postkoloniálnej teórie. Chandra Talpade Mohanty vo svojom kl'účovom texte Under Western Eyes spomína osobnú anekdotu: na základe „etnického“ oblečenia bola ihned' stotožňovaná s figúrou ženy tzv. tretieho sveta (tá, ktorá potrebuje pomoc). Pod sárí či šatkou však bola mladá žena vzdelaná v anglo-americkom systéme. Ako taká poznala matricu fungovania a budovania znalostného korpusu, poznala význam kritiky ako nástroja budovania tohto korpusu.

Podobne Gayatri Chakravorty Spivak nielen študovala anglickú a komparatívnu literatúru (v Indii a následne v Spojených štátoch, kde sa v roku 2007 stala prvou „,farebnou“ profesorkou na Columbijskej univerzite), ale tiež svojím prekladom sprístupnila Derridovu prácu anglo-americkému vzdelanostnému okruhu. Obe spomínané autorky boli naplno vnorené v anglo-americkom systéme poznania, a preto ho dokázali účinne kritizovat' a dopíňat' o nové (postkoloniálne aj feministické) perspektívy. Možno argumentovat', že ich kritika napomohla vyosit’ euroamerickú hegemóniu na poli teórie, no zároveň zostáva v medziach vytýčených určitým vzdelanostným systémom a tradíciou. 
Aby rané postsocialistické feministky prišli s kritikou na úrovni Under Western Eyes (1984) alebo Can the Subaltern Speak (1988), potrebovali presne to, o čo žiadali - čas. Čas na vybudovanie schopností osvojit' si diskurz, v ktorom boli feministické polemiky vedené. Presne tomu nás skúsenost' postkoloniálnej kritiky totiž učí: hlasy, ktoré nie sú dešifrovatel'né z pozície hegemónneho diskurzu, zostanú nevypočuté. Napríklad ich možno označit' za nekvalitnú argumentáciu, úplne mimo alebo jednoducho nudné.

\section{Problémy s formulovaním mocenskej nerovnováhy}

Aký feminizmus teda stojí v centre kritiky a prečo ho považovat’ za problematický? V tejto časti zaostrujem na tvrdenie, že raný postsocialistický feminizmus nepredstavoval širokú a vnútorne nesúrodú škálu teórií a náhl'adov, ale fungoval na značne konzistentnom ideologickom podloží. Kodíčková argumentuje, že raný postsocialistický feminizmus (v českom prostredí) sa kryštalizoval okolo polemiky s úzkym výsekom najmä liberálneho feminizmu, ktorý

staví na ideji univerzálních lidských práv, věří v univerzální patriarchální útlak žen a v globální sesterství založené na sdíleném utrpení a útlaku. Ty způsobuje uzavření ženy v soukromé sfére, tedy v rodině, která je pojata jako jeden z významných nástrojů útlaku ženy. Soustřed’uje se hlavně na ekonomické otázky a doufá, že nerovné postavení žen se vyrovná, když vstoupí do veřejné sféry, tedy především na pracovní trh a do politiky. Tento feminismus se zabývá pouze situací žen, které pojímá jako problémovou skupinu. Muže staví mimo ohnisko svého zájmu a implicitně (nebo i explicitně) jim přisuzuje vinu za neradostnou situaci žen. (Kodíčková 2002: 72)

Táto verzia feminizmu je výsledkom zjednodušovania viacerých akcií a debát, ktoré sa zvyknú periodizovat' pomocou symboliky vín (Hewitt 2012) ako prvá a druhá vlna feminizmu. Pole kritiky sa ustanovilo okolo pojmov patriarchát alebo sexistický útlak, ktoré poskytli reprezentačnú silu rozdrobeným problémom pocit’ovaným ženami v rozličných oblastiach.

Vel'mi skoro sa však takáto schéma stala predmetom d’alšej sofistikácie až dekonštrukcie. Jednak zdola na základe formulovanej skúsenosti tých žien, ktoré definícia obmedzovala či zneviditel'ňovala a svoju identitu kresali aj v rozpore so ženským politickým subjektom feminizmu daným bojom proti patriarchálnemu útlaku. V d'alšom pláne, ktorý však výrazne čerpal z tzv. hlasov zdola, bola základná feministická analýza problematizovaná z akademického prostredia (spomínané teórie tzv. farebných žien, postkoloniálne aj postštrukturalistické hl'adiská a d’alšia práca okolo kategórie rodu/genderu). Menej práce sa vykonalo ohl'adom skúmania politických východísk feminizmu ako jedného z emancipačných projektov (Mahmood 2005).

Loutfi (2009) prešetruje predpoklady určitej politickej skúsenosti zabudované do teoretických východísk a výskumných očakávaní feministických teoretičiek. Ukazuje, ako sú výskumné záujmy na poli women's/gender studies primknuté k širšiemu dobovému ideálu občianskej spoločnosti v náväznosti na rok 1968 a následne. Ideál spoločnosti, ktorá sa modeluje na základe skupín hlásiacich sa o svoje práva a adresujúce moc štátu v boji o uznanie svojich práv, významne ovplyvnil mladú disciplínu inštitucionalizujúcu sa v priebehu 70. rokov. Z tejto ideovej pozície, ako d'alej tvrdí Loutfi, je však iba určité spektrum aktivít vnímané ako 
nosné a sl'ubné pre feministický projekt a bádanie. Rozpoznat' možný ženský politický subjekt mimo rámec demokracií západného typu je preto častokrát otázkou kreatívneho využitia rozličných interpretačných sít (Abu-Lughod 1990; Karam 2002).

Podla Loutfi podobný problém zakúšajú feministické historičky obzerajúce sa po ženských politických formách pred obdobím osvietenectva, teda predtým, než boli započaté diskurzy oslobodzovania sa, vymaňovania sa zo závislosti a područia, výstavba samostatného a sebavedomého politického subjektu (Offen 2007). S týmito dilemami sa museli feministické teórie vysporiadavat' už niekol'ko desat'ročí a vel'mi skoro sa ukázalo, že rezignácia na feministický projekt (z hl'adiska kultúrneho relativizmu či historickej obmedzenosti) nie je riešením.

Fakt, že rodová/genderová analýza predstavuje markantný príspevok k porozumeniu procesov spoločenských premien a účinný kritický nástroj, sa dá najlepšie ukázat' na vydarených príkladoch. Napríklad Watson (1993) opisuje, ako sa agresívne podoby maskulinity stotožňovali s procesom prestavby pol'skej spoločnosti smerom k trhovému hospodárstvu. Vytvárala sa atmosféra výnimočného stavu, ked' sa údajne slabí musia stiahnut' z verejného priestoru, pretože nemajú tie správne vlastnosti, aby realizovali rázne opatrenia. Takáto podoba novej patriarchálnej úmluvy formujúcej sa v postsocialistických spoločnostiach si žiadala nové nástroje analýzy aj ochrany tých, ktorých mocenský diskurz odsúval mimo rámec úmluvy a podriad'oval si ich.

Avšak Watson nezostáva len $\mathrm{v}$ rovine nutnosti prenosov analytických nástrojov do nového prostredia, ale ukazuje, že dianie $\mathrm{v}$ tomto priestore zároveň použité nástroje mení. Tvrdí, že „dramatické zmeny v rodových vzt’ahoch vo východnej Európe poukazujú na mieru maskulinizmu v srdci západnej demokracie, ktorý tu [tam? Z. K.] bol len donedávne predmetom mlčania“" (Watson 2000: 38 [preklad Z. K.]). Zároveň upozorňuje, že jednoduché rozdelenie politických systémov na slobodné a neslobodné zneviditel'ňuje iné formy útlaku, ktoré sú tzv. slobodnému systému vlastné.

Ďalej politické podložie emancipačných projektov zvýznamňuje aj Ghodsee. Ukazuje, ako modernizačné diskurzy, ktoré raz rozdel'ovali svet na kapitalistický Západ a socialistický Východ, predstavovali vlastné verzie odpovedí na ,ženskú otázku“ (Ghodsee 2004: 732736), a tieto „riešenia“, dalo by sa spätne vyvodit’, podporovali legitimitu jednotlivých systémov. Inak povedané, tieto systémy šírili svoj mocenský záujem aj prostredníctvom vlastných emancipačných programov, ako som naznačila v úvode. Watson (2000: 39-40) napríklad poukazuje na to, ako sa problematika rodovej/genderovej rovnosti a práv tzv. sexuálnych menšín stali súčast'ou diskurzívnej stratégie americkej zahraničnej politiky, a žiada sa doplnit', že aj pevnou súčast'ou politík a etiky EÚ. ${ }^{10}$

Skúmanie problematiky prítomnosti tzv. Západného feminizmu v postsocialistickom priestore potenciálne otvára sériu nepohodlných, no rozhodne podnetných, otázok o politickej identite/identitách feministického projektu. Problematický nie je samotný projekt, ale zneviditel'ňovanie určitých ,samozrejmostí“, na ktorých stavia vo svojich zjednodušených a preskriptívnych formách. Ghodsee naznačuje, ako sa takáto verzia feminizmu stala súčast’ou

10 Nemálo feministiek staršej generácie aj antifeministické kritické hlasy si všimli, ako sa niektoré politiky EÚ ponášajú na štátnu emancipáciu spájanú s paternalistickým socialistickým zriadením. 
transformačných stratégií vrátane prenosu zavedených demokratických inštitúcií v procese premeny socialistických spoločností na tzv. spoločnosti otvorené, no najmä otvorené trhu.

Ponúknutá línia súvisu medzi tzv. NGO-izáciou (vnímanou aj ako zosúkromnenie sociálnych služieb, formovanie diskurzu a politík korporáciami, podchytenie aktérov vplyvu na verejnú mienku) a neoliberálnymi politikami, ktoré následne poškodzujú „slabých“, by si žiadala viac štúdií zameraných na lokálny kontext (bez nevyhnutného predpokladu, že zistenia z iných kontextov sú striktne prenositel'né). Zatial' preto možno najlepšie sledovat' diskurzívne línie vyjavujúce sa $v$ textoch domácich aj zahraničných feministiek a poukazujúce na určité hegemonické tendencie.

Boris Buden ([2009] 2013: 35-51) argumentuje, že transformačná ideológia vyžadovala, aby spoločnosti, ktoré si vydobili slobodu, boli náhle infantilizované - uvrhnuté do stavu bezmocnosti a vedené poručníkom na ceste k občianskym zručnostiam nutným pre správne užívanie demokracie. Otázky politického smerovania sa stali tabu a nahradilo ich prísne nasledovanie série receptov - Stark (1992) hovorí o „plánovanom kapitalizme“ (capitalism-by-design) a Ghodsee odpovedá termínom ,plánovaný feminizmus“ (feminism-by-design). Základným predpokladom tu zostáva podvolenie sa autorite poručníka a dôvera v poskytované recepty.

V tomto ohl'ade zohral tzv. Západný feminizmus viacnásobnú úlohu. Podl’a Zimmermann, Ghodsee aj Cerwonky jednak napomáhal výstavbe občianskej spoločnosti prostredníctvom pokladania vzdelanostných aj aktivistických sietí. Zároveň nepriamo pôsobil na budovanie podložia stabilnej klímy pre rozvoj podnikania, trhového hospodárstva a demokratického vládnutia. V nezanedbatel'nej miere tiež poskytoval servis - materiálny aj analyticko-teoretický - na liečbu (predpokladaných aj reálnych) neduhov, ktoré sa vynárali (napríklad maskulinizmus postsocialistických spoločností, ako ho identifikovala aj Watson 1993).

Predpoklad, že pri výstavbe nového poriadku sú ohrozené najmä ženy, bol zámienkou, aby do regiónu CEE prúdila sesterská pomoc tzv. Západných feministiek odhodlaných mapovat' situáciu a tiež pripravit' ženy (alebo aspoň ich zástupkyne) na rolu politického subjektu v tomto novom poriadku. Kodíčková aj Kampichler tak odvíjajú problémy raného feminizmu v CEE práve od pôsobenia družobných feministiek.

Kampichler (2012) vystopovala, ako sa zdanlivo komorná výmena názorov medzi Slavenkou Drakulić (1992) a Nanette Funk (1993) stala základným kameňom rozsiahleho a stále (aj ked' implicitne) trvajúceho tzv. dialógu medzi Východom a Západom. Ked' už raz bol tón dialógu udaný, pokračovalo sa vo vymedzených schémach. Síce sa tzv. Východné feministky snažili formulovat’ kritické stanoviská k vlastnej podradenej pozícii, no v jadre zostávali politicky porazené a posadené do školských lavíc demokracie aj feminizmu.

To si z časti uvedomovali aj následné feministické kritičky, ktoré formulovali problémy vo vzt’ahu medzi tzv. Západným a Východným feminizmom. Cerwonka (2009) zachytila hlasy, ktoré tvrdili, že domáce teoretičky sú častokrát používané ako zdroj dát a skúseností, no d’alej sú poznatky rámcované tzv. Západnými autorkami. Možno teda hovorit' o akejsi akademickej exploitácii, ked' tzv. Východné feministky boli mediátorkami, kontaktnými osobami, priatel'kami, koordinátorkami, znalkyňami kontextu aj lokálnych jazykov, no postrádali požadované akademické know-how, aby sa presadili v globálnom akademickom rámci určovanom angloamerickými štandardmi. Nejde tu teda len o formulovanie tej správnej teórie pre región, 
ale tiež o boj o prístup k zdrojom, kariérne dráhy, znalostnú hegemóniu a podobne (aj ked' netreba podcenit' inšpirujúce stretnutia a úprimné spojenectvá, ktoré mnohé rané feministky zdôrazňujú).

Sebareflexia zabudovaná do princípov disciplíny vel’mi skoro rozprúdila záujem o tzv. lokálne hlasy, autentické myšlienky, postoje a skúsenosti. Formulovanie skúsenosti cez biograficky ladené príbehy ponúkalo možnost' zúčastnit' sa debát a zdiel'at' svoje predstavy aj tým ženám, ktoré sa (ešte) neorientovali v žargóne feministických teórií (Juráňová a Cviková 2009a: 72). Zároveň treba poznamenat', že tieto skúsenosti boli častokrát zarámované hrubotesaným rámcom patriarchálnej premisy, ked' autorky dospeli k formuláciám v zhode s importovanou zjednodušujúcou verziou feminizmu.

Výsledkom ret’azca zjednodušení je napríklad aj takáto formulácia: „V bývalom Československu ako aj v iných postsocialistických krajinách bola politika a verejnost' definované z mužskej perspektívy a cez mužskú skúsenost'. Táto skúsenost' sa považovala za bezpríznakovú a rovnako vhodnú pre mužov aj ženy. My sme však výrazne pocit'ovali, že to nie je naša skúsenost““ (Cviková a Juráňová 2009a: 74 [preklad Z. K.]). Takéto pozorovanie má samozrejme obrovský potenciál v rámci domáceho prostredia a nemožno ho celkom vystrihnút' z kontextu práce zakladateliek Aspektu, ktoré roky pracujú na scitlivovaní rodovej optiky verejnosti. Napriek tomu sa uvedený výrok dá vnímat' ako reprezentatívny, príznačný a prezrádzajúci trend, ktorým sa uberala rodová/genderová analýza napojená na takúto „,autentickú“ skúsenost'. ${ }^{11}$

Možno teda polemizovat', či pojem feministickej skúsenosti vzniká dodatočne pod vplyvom prevrstvenia zážitkov, udalostí a súvislostí na základe feministických naratívov, alebo je výsledkom demaskovania patriarchálnych vzt’ahov, ktoré predtým zostávali v rovine neuvedomelého skúsenostného materiálu. Takýto materiál sa vyzráža cez poskytnutý pojmový aparát do podoby rámcovanej feminizmom a okamžite sa stáva výskumnou surovinou; potvrdzuje tak optiku rodu/genderu. Poučení postštrukturalizmom tušíme, že takáto mediácia cez pojmový aparát feminizmu daný diskurz nijako nelegitimizuje, ked’že nemediovaná, surová skúsenost' nie je dostupná či komunikovatel'ná. Dôležité je, myslím si, pripomínat' si prítomnost' tejto mediácie a jej funkcie.

Podla Zimmermann aj Ghodsee malo zavedenie alebo zvýznamnenie výskumnej kategórie rodu/genderu za následok odliv síl z pol’a kritiky prudkej stratifikácie postsocialistických spoločností. Aktivistky, akademičky, intelektuálky aj umelkyne totiž preostrili svoj záujem smerom k skúmaniu novej kategórie. Nejde o to, určit' priority pre kritiku ustanovovania mocenských nerovností a neprávostí. Autorky netvrdia, že triedna kritika by mala predchádzat' a v konečnom dôsledku pohlcovat' rod/gender, ako to tvrdili architekti emancipačných politík počas socializmu. ${ }^{12}$ Ghodsee (2004: 748) navrhuje, že namiesto šírenia „plánovaného

11 Presnejšie vyjadrila vzt’ah rodu k štruktúram autoritárskej štátnej moci napríklad Wagnerová (1999) v príspevku České ženy na ceste od reálneho socialismu k reálnemu kapitalismu.

12 Napokon sám Lenin údajne odsunul problémy formulované ženami pod vedením Kollontai. Ako sa ukázalo, je to aj tento opakovaný moment odkladania záujmov ženských účastníčok v rámci väčších emancipačných projektov (národných, anti-koloniálnych či prodemokratických), čo nútilo tieto ženy odlučovat' a radikalizovat' sa. 
feminizmu“ by analýza rodu/genderu mimo kontextu kapitalizmu mohla predstavovat’ šancu pochopit túto kategóriu v nových súvislostiach, a to aj v súvislosti s prestavbou sociálnej stratifikácie (Fodor 1997). Ďalej by tak bolo možné spolu s Watson a Loutfi odkrývat' zabudované „samozrejmosti““ vyplývajúce z politického, spoločenského a kultúrneho DNA konceptu $\mathrm{rodu} /$ genderu.

Takáto požiadavka však už môže byt' z časti passé, ak bola kedy uskutočnitel'ná v „,autentickej“ podobe. Rané sympatizantky feministických teórií a rodovej/genderovej analýzy totiž spočiatku nehovorili plynulo akademickým jazykom družobných feministiek (Šmejkalová 1998: 18). Ked' si následne ich žargón a kritické návyky osvojili, dalo by sa povedat', že modulovali svoj hlas (vrátane zásobníka autentickej skúsenosti a pamäte) a puzdro „dizajnovaného“ ženského politického subjektu k nim tesne prirástlo. Opät’ sa tu vynára odkaz na Spivak, ktorá tvrdila, že hlasy mimo hegemónie nikdy skutočne nemôžu zazniet'. ${ }^{13}$

V náväznosti na takúto výhradu možno pochopit’ smer, ktorým sa vybrala feministická teória nielen v CEE. Formuloval sa výrazný prúd teórie zaoberajúcej sa prenosom poznania a jeho ukotvovania/prejednávania $v$ lokálnych kontextoch. Dalo by sa poznamenat', že takéto snahy dnes najlepšie charakterizujú európsky akademický feminizmus. Za pozornost' stojí napríklad projekt Travelling Concepts in Feminist Pedagogy: European Perspectives (Cestujúce pojmy vo feministickej pedagogike: Európske perspektívy) prepájajúci katedry a centrá rodových/genderových štúdií naprieč kontinentom a koordinujúci obsah syláb, ciel’ov výuky a pojmového slovníka.

Dalo by sa prípadne vysledovat', nakol'ko je tento záujem o prenos teórií zakotvený v staršej feministickej debate medzi Východom a Západom a v snahe tzv. Východných feministiek o popísanie svojich problémov s prenosom znalostí a so zadefinovaním vlastnej identity cez feministické kategórie. V rámci debaty Východ-Západ Blagojević (2006) napríklad tvrdila, že tzv. Východné feministky sú vylúčené z produkcie teórie a slúžia len ako prenášačky a uživatel'ky poznania zo Západu, zatial'čo Gal a Kligman (2000) tlmočili ponosy, že Východné feministky sú pripustené výlučne len k produkovaniu poznania o svojom regióne a zovšeobecňovanie z ich „,špecifického“ hl'adiska sa zdalo byt' vylúčené.

Idea sesterstva žien, ktorá charakterizuje solidarizovanie sa okolo pojmu patriarchátu, však paradoxne nedostala trhliny na základe spomínaných kritík, ale práve tieto diskusie zadefinovali novšiu podobu (európskej) feministickej solidarity ako sústavného vyjednávania spojníc a odlišností.

Myšlienka družby, spojení a kontaktov však zostáva v centre kritického záujmu tých feministických teoretičiek, ktoré sa viac než na radostné združovanie a výmenu skúseností sústredia na obt’ahovanie mocenských liniek aj prostredníctvom zavádzania kategórie rodu/

13 Táto polemika sa podobá (s trochou irónie) diskusii o tom, nie či je mimozemský život, ale či by sme ho boli schopni postrehnút'. Hegemónia totiž nastavuje naše zmysly tak, že len určité formy poznania vyzerajú ako poznanie. Sú to práve kritické disciplíny vychádzajúce zo spoločenských hnutí (ako gender studies), ktoré rozpracovali diskusiu o prepojení moci a poznania, (ne)možnosti formulovania autentickej skúsenosti a poukázali na to, ako zavedené disciplíny podporujú status quo aj tým, že ho jednak legitimizujú, dávajú mu ráz objektivity, nevyhnutnosti a kultúrnosti a tiež reprodukujú hierarchie cez sito vzdelávania. 
genderu do výskumnej aj pedagogickej agendy v regióne CEE. Podl’a Kodíčkovej prvotný komunikačný problém vyplýval z nádejí družobných feministiek, že $\mathrm{v}$ postsocialistických krajinách budú svedkyňami utvárajúceho sa silného ženského hnutia podobne, ako tomu bolo v 70. rokoch v Spojených štátoch. ${ }^{14}$ A d’alej vysvetl'uje:

Tyto „západní feministky“, jak samy konstatují [...], patří ke generaci, která vyrostla v atmosfeře optimismu a nadšení ženského hnutí let sedmdesátých (a tedy ve viře v jednotný ženský osud), a přivezly s sebou právě [úzko poňatý liberálny] feminismus [...] s nadějí, že zde vybudují (masové) ženské hnutí analogické tomu, s nímž samy vyrůstaly. (Kodíčková 2002: 74)

Takýto feminizmus by mohol byt' vnímaný ako vývoz prežitých ideí prirovnatel'ný (pri troche cynického naladenia) $\mathrm{k}$ zastaraným počítačom a nepredajným kolekciám šiat, ktoré prúdili do bývalého východného bloku.

Kampichler (2012) totiž d'alej upozorňuje, že v čase, ked' rané postsocialistické feministky viedli dialóg s družobnými feministkami - napríklad o i/relevancii rozdelenia sfér na ženskú privátnu a mužskú verejnú (Kiczková a Farkašová 1993) či o ne/vôli žien zapojit' sa do pracovného procesu a politickej reprezentácie (Havelková 1993; Šiklová 1993) -, existovala už robustná kritika konceptuálnej hegemónie strednoprúdového feminizmu (spájaného najmä so Spojenými štátmi americkými, ked’že práve tu sa feministické teórie inštitucionalizovali už od začiatku 70. rokov).

Na viacerých frontoch mu bolo vytýkané, že zovšeobecňuje problémy bielych heterosexuálnych (Západných) žien strednej triedy (s určitou politickou skúsenost’ou) ako ženské problémy per se a vytesňuje tak iné hlasy žien a kolonizuje ich svojimi požiadavkami na jediné pravé oslobodenie. Tieto kritiky trieštili univerzalistické predpoklady formulované feministkami druhej vlny najmä v Spojených štátoch a zároveň riešili spôsoby, akými sa tzv. farebné ženy a ženy z postkoloniálnych kontextov vzt’ahujú k feminizmu. Na poli feministickej teórie tak už fungovala značná teoretická výbava, ktorá jednak uchopovala rod/gender ako komplexnú analytickú kategóriu neredukovatel'nú na pohlavnú diferenciu dvoch d’alej neštiepitel'ných entít „muž“ a „žena“ a tiež formulovala rod/gender ako vzt'ahmi podmienenú, silne kontextuálnu kategóriu (Šmausová 2002).

Rané feministické teoretičky a aktivistky sa ocitajú v paradoxnej situácii, ked' jednak upozorňujú na situáciu žien, no zároveň reprodukujú hierarchie poznania a moci na linke Východ-Západ a to tak, že preberajú kategórie výskumu, ktoré im ponúka tzv. Západný feminizmus. Tento paradox si samozrejme uvedomovali a snažili sa ho sformulovat' (napríklad Drakulić 1992; Havelková 1993; Šiklová 1993; Šmejkalová 1997). Kodíčková zostáva nepresvedčená kritikami jednotlivých rozdielov. Nešlo tu totiž o skutočný rozpor, len o „napratávanie" skúsenosti postsocialistických žien do konceptuálnych formičiek, ktoré boli navyše už $\mathrm{v}$ tom čase hrdzavé a nezodpovedali ani spoločenskej situácii na tzv. Západe.

Kodíčková a Kampichler si d’alej zhodne uvedomujú, že skutočným limitom kritiky nebol úzky záber „importovaných“ feministických teórií (napokon časopis Aspekt ponúkal

14 V publikácii Gender Issues 2009: Gender Equality Discourse in Times of Transformation, 1989-2009 (The Czech Republic, Poland, Slovakia and Ukraine) autorky zo Slovenska a Česka uvádzajú najmä kontakt s akademičkami a aktivistkami zo Spojených štátov, Nemecka a Rakúska. 
od roku 1993 do 2004 bohatý register prekladových textov z teórie aj beletrie - najmä z angličtiny a nemčiny v náväznosti na jazykovú výbavu zakladateliek). Obe kritičky identifikujú ako najdôležitejší faktor znemožňujúci účinnú kritiku ohraničenie politickej imaginácie.

Podl'a Budena (2013: 48) sa v postsocialistických spoločnostiach stala otázka politického smerovania absolútnym tabu - dodala by som, že aspoň na čas a v istých kruhoch. Isté je, že aj v prístupoch raných postsocialistických feministiek možno nájst' stopy, ktoré tam zanechali pôsobivé transformačné diskurzy. V nasledujúcej časti poukážem aspoň na dva, ktorým sa venovali aj Kodíčková aj Kampichler - ideu Vel'kého návratu a Imaginárneho Západu - a doplním ich o preskúmanie rétoriky poručníctva a idey normálnosti, ako o nich písali Buden (2013), Kiossev (2008) či Vasilescu (2008).

\section{Viera vo Vel'ký (ženský) návrat}

Kampichler (2012: 11) sa v priebehu svojej analýzy pýta, ,proč české autorky kromě historické zkušenosti žen netematizují zároveň i současnou situaci lokálních žen (např. ve smyslu globálních ekonomických a politických souvislostí), ani nekritizují západní feminismus v duchu Mohanty jako feminismus reprodukující mocenské vztahy[?]“.

Následne ponúka ako odpoved' „projev uznané nadřazenosti“ (tamtéž) zo strany tzv. Východných feministiek; v tomto bode sa zhoduje s Kodíčkovou. Tá d’alej ponúka náhl'ad do histórie myslenia, v ktorom je svet podelený na zóny civilizácie a zaostalosti a kde si normy uzurpuje tzv. Západ, takže tí, ktorí sa ocitli mimo centra, sú zároveň prit’ahovaní predstavou o dobiehaní, vyrovnaní sa, modernizácii; no takýto projekt zostáva bez úspechu, ked’že podmienky sa menia počas sút’aže a dobiehajúci na ne nemajú vplyv.

Navyše, ako ukázala na príklade tzv. balkánskych krajín Todorova (1997), sút’ažiaci sú pohl'adom fixovaní $\mathrm{k}$ rozhodcovi a miesto vzájomnej solidarity strategizujú pomocou osočovania tých druhých zo zaostalosti a vyzdvihujú tak vlastné zásluhy, aby prináležali k táboru civilizovaných. Kiossev (1999) d'alej popisuje, ako boli bulharské elity už od dôb osvietenstva $\mathrm{v}$ sústavnom napätí medzi obdivom k civilizačným vzorom a hanbou zo zaostalosti vlastného l'udu. Takáto rozčesnutost’ medzi ideou „modernizovaných“ elít a „zaostalého“ l'udu je citel’ná v regióne CEE dodnes a stálo by za zváženie preskúmat', ako sa takáto schéma odráža v tzv. antifeministickom paradoxe, ktorý vypozorovali aj Watson (2000) a Cîrstocea (2009).

Kodíčkovej analýza ide za hranicu púheho obvinenia raných postsocialistických feministiek zo sebakolonizačných tendencií. ${ }^{15}$ Východné feministky nie sú paralyzované snahou ospravedlnit' sa za odlišnosti a následne tieto odlišnosti odstraňovat'. Viera v prirodzenú nadradenost' Západu totiž stojí v centre ich uvažovania a je motorom ich konania. Dalo by sa povedat', že ich stimuluje a motivuje, ked’že približovanie sa Západu sa zdalo byt'

15 Kodíčková charakterizuje sebakolonizáciu v náväznosti na Leelu Gandhi (1998) ako zatracovanie vlastnej odlišnosti, ktorá sa zdá byt’ problematická až nenormálna, častokrát vzbudzuje sebanenávist' a potrebu zmenit' sa. Kiossev dokonca na túto tému napísal encyklopedické heslo pre online projekt Atlas of Transformation. Častokrát sa takýto reflex odráža vo výlučnom odkazovaní na Západné pramene a nezáujem o intelektuálne dianie v okolitom priestore. 
nevyhnutnost’ou. Podl'a Budena totiž v krajinách CEE ekonomický determinizmus hladko nahradil (marxistický) determinizmus historický. Ako d’alej tvrdí Kodíčková, z tohto hladiska by užívanie kritického potenciálu postkoloniálnej teórie rušilo. Lavicové až anti-imperiálne zameranie postkoloniálnej kritiky by bolo nahliadané v kontexte transformácie ako problematické, ak aj nie celkom nemyslitel'né.

Niektoré teoretičky sa síce snažili korigovat’ kategórie ponúkané Západnými feministkami, no neobviňovali ich v duchu postkoloniálnej teórie z diskurzivnej kolonizácie (Mohanty 2003) či implicitnej účasti na neo-imperiálnom projekte pod rúškom demokratizácie, ktorého súčast’ou by mala byt' aj emancipácia na spôsob Západného feminizmu. Takéto výčitky zčasti vznášajú aj Ghodsee a Cerwonka, ktoré si však toto výrazivo môžu dovolit' (dokonca ním osvedčujú svoju príslušnost' k určitým vzdelanostným prostrediam), zatial'čo v kontexte stredoeurópskej akadémie či verejnej diskusie 90 . rokov by podobný slovník znel prinajmenšom komicky (v posledných rokoch sa vracia okl’ukou z prostredia kritických disciplín anglo-americkej tradície ako cultural studies alebo aj gender studies).

Ako usúdila aj Kampichler, rané feministky vnímali odlišnosti deliace Východné ženy od tých Západných ako zavinené historickou skúsenost'ou a teda dočasné, odstránitel'né na ceste $\mathrm{k}$ splynutiu so Západom, kam kunderovská stredná Európa $\mathrm{v}$ ich ponímaní prirodzene patrila. Paradigma Vel'kého návratu zostáva implicitne prítomná v mnohých textoch, kde zaznieva predpoklad, že zameškané bude dobehnuté, nerovnost' bude narovnaná a ženy prirodzene nájdu svoje miesto $\mathrm{v}$ novej spoločnosti, ked’ si uvedomia a rozvinú vlastnú individualitu vrátane vlastnej ženskosti potlačenej žitou realitou socialistickej emancipácie. Vel'kým návratom tu myslím zmes diskurzov o právoplatnom mieste strednej Európy v demokratickej Európe, o legitímnom navrátení sa $\mathrm{k}$ tzv. západnému civilizačnému okruhu. Takýto návrat predpokladá popretie relevancie predchádzajúceho obdobia, vníma ho ako chybu, odbočku od skutočnej cesty, a žiada nápravu.

Watson (2000: 38) poznamenáva, že transformácia identity ako objavovanie skutočnej, vlastnej, nedeformovanej podoby stojí v centre dobových predstáv o demokratizácii. Pre rané feministky je to navyše snaha o objavenie „skutočnej“ ženskej identity, rozvíjanie ženskosti a záujem o dejiny žien. Doteraz totiž ,nemali šancu uvedomit' si a určit' samé pre seba, čo to znamená byt' ženou, a vyjadrit' to vo svojich životoch, spoločenských rolách a osobných očakávaniach“ (Kiczková a Farkašová 1993: 87 [preklad Z. K.]). Podl’a Šiklovej (1993) sa české ženy len dočasne a strategicky priklonili k (zdanlivému) konzervativizmu: po rokoch nanútenej politickej participácie a zamestnanosti sa totiž túžia nezúčastňovat' verejného života, venovat' sa rodine a pestovat' svoju ženskost' ako odlišnost'.

Kiczková a Farkašová (1993) formulujú prínos tzv. Západného feminizmu pre „naše“ ženy v tom, že im napomôže k sebavedomej existencii, ked' nebudú svoju identitu odvodzovat' od sebaobety, ale dokážu sa rozvinút' ako osobnosti, pretože len ako také sa dokážu plnoprávne zapojit' do spoločnosti - ako pracovníčky, občianky aj partnerky a matky. Takýto názor sa odvíja od predstavy, že ženy by mali byt’ rovnoprávne na základe svojej (preskúmanej a pestovanej) inakosti.

Podobne aj Cviková a Juráňová (2009a) volajú po uznaní ženskej skúsenosti a hl'adiska (po rokoch nanútenej rovnosti, ktorú predstavuje projekt socialistickej emancipácie). Dávnejšie to formulovali aj Kiczková a Farkašová (1993: 93), ked’ vyzývali, aby sa nový 
emancipačný projekt nezakladal na formálnej rovnosti založenej na falošnej neutralite, ale naopak začal od odlišností, potvrdil ženskú špecifickost', identitu.

Predstavy o novej, rodovo/genderovo spravodlivejšej spoločnosti dostávajú v textoch raných feministiek črty (špecifického transformačného) kultúrneho feminizmu, ktorý predpokladá a kultivuje esenciálnu ženskost'. Predpoklad je tu asi takýto: ženská identita potláčaná a deformovaná dvojitým zat’ažením - patriarchátom aj totalitným režimom - sa konečne vystiera do svojej pravej podoby. Takáto znovuzískaná identita sa má stat' základom pre účast' žien na novom poriadku, dokonca na vyformovaní takého poriadku, ktorý by lepšie odrážal potreby žien, nie však ako prosebníčok za práva, ale ako hodnotnejších účastníčok.

Nešlo tu samozrejme o mocenský zápas, ale o zmenu paradigmy smerom k tzv. ženským hodnotám. Šiklová (1993: 82) píše: „Dúfam, že ženy vytvoria iný spôsob [vládnutia?, hodnôt? Z. K.], než muži, ktorí sa orientovali na individuálny úspech, konzum a osobnú moc“. Podobne Wagnerová (1999: 89) formuluje prínos feminizmu k novému poriadku sveta, ktorý by mal blízko k ekologickej etike - od dôrazu na produkciu by sa prenieslo hl'adisko k reprodukcii, čiže zachovávaniu, starostlivosti a spolupráci. K vel'mi príbuzným návrhom sa dopracoval z antifeministického hl'adiska aj Komárek (2012) a nutnost' zmeny paradigmy dokladá miznutím tradičných ženských hodnôt údajne pod vplyvom feministického projektu, čo len svedčí o tom, že feministické diskurzy nestihli „ovládnut'“ diskusiu, ba dokonca ani vysvetlit', o čo im (z rôznych hl'adísk) ide.

Napriek identifikovaným transformačným diskurzom prítomným v rétorike mnohých autoriek by sa dalo predpokladat', že zamýšl'aný ženský politický subjekt sa formoval nielen ako antitotalitný, antipatriarchálny, ale aj (implicitne) antikapitalistický a vskutku prezentoval snahy raných feministiek po formulovaní hybridného systému, utopickej verzie spoločnosti inšpirovanej hoci aj feminizmom ,po dátume spotreby,“ ktorý sa však slovami Anny Daučíkovej ,javil sa ako jediná možnost', ako zostat' v kritickej opozícii voči tomuto svetu“ (Cviková a Juráňová 2009a: 48).

Ghodsee zachytila diskurzy o esenciálnom ženstve ako politickej nádeji aj vo viacerých zborníkoch zaoberajúcimi sa situáciou a vyhliadkami žien v postkomunizme (Einhorn 1993; Holmes 1997; Jaquette a Wolchik 1998). Opät’ tu ide o prenesenie nádejí tzv. Západných feministiek do nových kontextov, kde sú ženy jednak znevýhodňované, ale aj schopné výrazne napomôct' spoločenským zmenám, ak sa im v úvodnej fáze pomôže. Ženy sú tak vnímané ako „rezervná armáda“ celospoločenských zmien (podobne ako v postkoloniálnych rozvojových diskurzoch). ${ }^{16}$

Prizma objavovania/utvárania ženskej identity rozhodne ponúkla fascinujúce interpretačné možnosti, možnosti prepájajúce čítanie sveta naokolo s prehodnocovaním vlastnej

16 Otázne zostáva, či táto „rezervná armáda“ nachýli vývoj dol’ava, ako predpokladá Ghodsee, ked” uvažuje, čo sa stane, až aktivizované ženy začnú volit’ sledujúc tie strany, ktoré lepšie vyhovujú ich záujmom (tu sa Ghodsee opiera o štatistiku Prospects for Gender Equality Policies in Central and Eastern Europe) a tým pádom podryjú autoritu inštitúcií zastávajúcich neoliberálne politiky a podporujúce NGO-izáciu v CEE (2004: 746); obrátia sa tak vlastne proti tým, ktorí ich aktivizovali. Viac skepse preukázala Fraser (2009), ked' sledovala, ako boli za posledné desat'ročia feministické riešenia a nádeje účinne pretavené v súlade s neoliberálnymi politikami. 
identity - takéto presuny pojmov aj energie boli určite $\mathrm{v}$ dobe spoločenských premien intelektuálnou vzpruhou. Interpretácie dávajúce na prvé miesto rod/gender zaujali teoretičky z rozličných prostredí naprieč názorovým spektrom. Nečudo teda, že napríklad slovenský feministický vzdelávací projekt Aspekt pritiahol do svojho okruhu ženy v umeleckých aj akademických profesiách. Zjednodušene povedané feminizmus ponúkol istej skupine žien ideologickú útechu v časoch konceptuálnej neistoty a pomohol im zacielit' energiu, aktivizovat' sa. Teória tu zčasti nadobúda efekt meditačného cvičenia - neuvedomelé ženstvo sa zrazu zvýznamňuje, precituje a brní netušenými možnost’ami.

Rovina osobnej inšpirácie, možnosti združovat' sa, vzdelávat' a pýtat' sa nové kritické otázky sa v prísnom zábere na tvorbu infraštruktúry a prenos poznania (Zimmermann, Cerwonka, Ghodsee, Cîrstocea) vytráca. Prítomná je naopak v biografických príspevkoch, ktoré predstavujú zborníky Nové čteni světa (Chřibková 1999) alebo Feminizmy pre začiatočníčky (Cviková a Juráňová 2009a). Kým prvý zborník neponúka rámcovú analýzu jednotlivých príspevkov, ten druhý zase ukotvuje spomienkové prehovory účastníčok okrúhleho stola v rámci Novembrovej tématiky, demokratizácie a antinacionalizmu. Aspektovský rámec tak vykrajuje špecifickú politickú líniu slovenského postsocialistického feminizmu.

\section{Odložený feminizmus}

Zatial'čo medzi určitou úzkou skupinou myšlienky feminizmu rezonovali, dalo by sa povedat', že išlo o obmedzený kontakt, ktorého ciel'om bolo tento kontakt multiplikovat', sprostredkovat'. Ako som už uviedla, Kodíčková (2002: 74) tvrdí, že v začiatkoch niektoré tzv. Západné feministky ešte verili, že sa im podarí dat' do pohybu feministické hnutie v rozsahu, aký si pamätali zo 70. rokov.

Kontakt s tzv. Východom znamenal pre aktivistky a akademičky jednak zaujímavú pracovnú príležitost', no ponúkala sa tiež šanca preniest' svoje skúsenosti a pracovat' so ženami, ktoré vnímali ako ohrozené a slabo si uvedomujúce rodovú/genderovú identitu, okolo ktorej by sa mali združit'. Zároveň však (mnohé) neboli schopné citlivejšieho etnografického prístupu, ked’ by nechali samotné kategórie vynárat' sa z terénu. Havelková (1993) situáciu popisuje vel’mi diplomaticky a zmierlivo, ked' označuje tzv. Západný feminizmus za zdroj inšpirácie a obohatenia znalostného aj osobného rozvoja. Zároveň však poznamenáva, že zoznámenie sa s týmito zdrojmi a čerpanie z nich predpokladá, že „prekonáme kultúrnu izoláciu a rozvinieme príslušné disciplíny, čo je primárne otázkou času“" (1993: 62 [kurzíva Z. K.]).

Podobne aj Juráňová (2009: 22-23) nabáda k dobiehaniu zameškaného a pravdepodobne má na mysli pretrhnutú nit' záujmu o rodové/genderové politiky aj feministické teórie zo Západu. ${ }^{17}$ Šiklová (1993) formuluje požiadavku, ba dokonca prosbu: „Dajte nám čas

17 Havelková upozorn̆uje na diskusiu, ktorú vyvolalo vydanie Druhého pohlavia Simone de Beauvoir, klasičky Západného feminizmu inšpirovanej existenciálnou filozofiou, štrukturalizmom a marxizmom; debata prebehla v roku 1967 na stránkach Lidových novin a Havelková ju prisudzuje vplyvu atmosféry Pražského jara (2011: 93). Možné porovnanie sa ponúka s vydaním Pani Dallowayovej, modernistického románu Virginie Woolfovej, ktorý vychádza v 1976 v bratislavskom nakladatelstve Smena v „edícií svetovej prózy o ženách a pre ženy“ v ružovej obálke (s ilustráciami Jany 
na sebaobjavovanie. Potom budeme môct' byt' vám partnerkami v dialógu a v hnutí“ (Šiklová 1997: 81 [kurzíva Z. K.]). Viaceré teoretičky teda videli potrebu tzv. Západného feminizmu odloženú do budúcnosti a to jednak v prípade, že sa životný štandard priblíži tomu Západnému a teda relevancia feminizmu akosi vyplynie z okolností (Kiczková a Farkašová 1993; Šiklová 1993), prípadne sa ženy budú rodovo identifikovat’ na základe spoločných problémov, ktoré zmeny priniesli, ako komodifikácia ženského tela alebo zvýšená nezamestnanost' (Drakulić 1992). „Misia“ feminizmu sa tu z časti vníma ako akási poistka nastávajúceho poriadku, ktorý má tendenciu slepo produkovat' zisk, bez ohl'adu na prekérne existencie či hranice etiky. Parafrázujúc Slavenku Drakulić: niet kapitalizmu bez feminizmu.

Dôležité je všimnút' si tiež, ako však takýto odložený feminizmus zároveň podlieha ideológii transformácie a predpokladá Imaginárny Západ ${ }^{18}$ ako ciel' transformačnej cesty, ktorá mala pre určité diskurzy pestované v krajinách strednej Európy aj špecifickú hodnotu návratu. Kodíčková hovorí o konštrukte Západu, ktorý sa zakladá na ,ideálnej, vskutku utopickej spoločnosti““ (2002: 79). ${ }^{19}$ Prechod do tejto spoločnosti potreboval zhovievavú pomoc aj pozorné ucho. „Prosím, tolerujte našu odlišnost'. Dajte nám čas a priestor,“ hovorí Šiklová (1997: 81).

Stratégiu prihovárania sa imaginárnemu publiku si niektoré autorky osvojili pokračujúc v šl'apajach disidetských diskurzov. Kiossev (1999) ukazuje, ako si stredoeurópski opoziční intelektuáli zvykli obracat' sa k tzv. Západu, volat' ho za svedka, prezentovat' sa pred ním s ponosami. Transformačné diskurzy d'alej t’ažili z tohto nastavenia elít aj verejnosti, zo snahy obstát' a začlenit' sa, normalizovat' sa (Kiossev 2007; Vasilescu 2007). V takomto nastavení je kritika a konflikt vylúčená a jediným riešením zostáva, ako sa zdá pri pohl'ade naspät', žiadat' čas a zhovievavost's inakost'ou, ktorá v zásade musí (nevyhnutne) byt' prekonaná.

Želibskej, ktorej tvorba bola zčasti inšpirovaná feminizmom, ako ukázala jej retrospektíva v bratislavskej SNG v roku 2012), no štylizovaný ako čítanie pre ženy. Otvára sa otázka, ako boli koncipované produkty Západného feminizmu a ako zapadali do rodového poriadku neskorého socializmu, ktorý zvykneme vnímat' aj na základe kritík emigrantskej vlny teoretičiek ako stagnujúci a odkláňajúci sa od progresívnych politík emancipácie ku konzervatívnejšej verzii patriarchátu. Požičiavam si Yurchakov (2006) koncept Imaginárneho Západu („Imaginary West“), ktorý anekdoticky mapuje a dokladá na príkladoch z ruskej popkultúry 80. rokov a ktorý sa v závanoch t’ahal obdobím transformácie.

19 Takto Kodíčková charakterizuje Imaginárny Západ: „Funguje zde parlamentní demokracie (kde voliči zodpovědně sledují politické dění, politické strany i politici naslouchají občanům, doopravdy je reprezentují a věcně řeší nastalé problémy); zodpovědná vláda dbá o obecné blaho, které je vždy definovatelné a vyjednatelné; hospodářství prosperuje a nepotřebuje státní zásahy; všichni občané jsou si rovni, požívají svobody ve všech podobách, kterou ovšem nezneužívají, protože jsou zodpovědní k sobě i ostatním; média a věda jsou objektivní, nezaujaté a neúplatné; funkční byrokracie a minimální stát nemají sklon se rozpínat. To vše se připisuje západním, civilizovaným, vyspělým společnostem a mezinárodním institucím, jejichž názory a rady jsou v důsledku takové vyspělosti pro nás závazné.“ (Kodíčková 2002: 79) 


\section{Východ-Západ: dialóg bez konfliktu?}

Ghodsee a Cerwonka predpokladali, že nové interdiciplinárne programy vrátane rodových/ genderových štúdií a mimovládne organizácie pridružujúce rodové/genderové aspekty k agende l'udských práv a demokratizácie účinne odviedli pozornost' od kategórie triedy a ponúkli spoločenským vedcom/vedkyniam a aktivistom/aktivistkám nové čtení světa, novú paradigmu, cez ktorú možno formulovat' problémy hodné výskumu a politík. Podl'a Ghodsee (2004: 728) importovaný tzv. Západný feminizmus „hl'adá spôsoby nápravy najhorších prečinov patriarchátu, no zároveň nikdy nespochybňuje sociálne a ekonomické vzt’ahy, na ktorých patriarchát stoji“". Rod sa tak stáva prierezovou kategóriou predpokladajúcou univerzálnu nevýhodu žien. ${ }^{20}$

Kategória triedy sa však celkom nevytratila; zmutovala a primkla sa k debate o znevýhodnenom Východe a privilegovanom Západe. Charakteristikou mytológie Západu ako dedičstva rozdeleného sveta je široko zdiel'aná predstava západného blahobytu oproti východnému nedostatku. Trieda tak stráca pôvodnú analytickú silu a postsocialistická populácia ako taká sa stáva chudobným pribuzným Západu. ${ }^{21}$

Takýto postoj možno vystopovat' na príkladoch viacerých formulácií z pera „našich“ feministiek. Napríklad Šmausová (2011 [2006]: 205 [kurzíva Z. K.]) poznamenáva na margo odlišností tzv. Západného feminizmu, že „,̌eské ženy stěží měly čas na reflexivní sebeuvědomování se v terapeutických a teoretických skupinách, na čtení alternativních feministických časopisů apod.“. Západné ženy sú tu vykreslené ako materiálne zabezpečené meštiačky, pre ktoré je feminizmus nástrojom k sebaspytovaniu a upevňovaniu individuality oslobodenej z patriarchálneho referenčného rámca. S nadsázkou sa takto poňatý meštiacky feminizmus podobá krúžkom jogy či sedeniam u psychoanalytika.

Podobne Kiczková a Farkašová (1993: 93) prepokladajú individualizáciu (self-advancement) žien, ktorým má feminizmus pomôct' v prerode od ženy určenej vzt’ahmi k druhým k samostatnej bytosti, ktorá rozhoduje o svojich zväzkoch. Použivajú tu figúru starej matky, ktorá je charakterizovaná žitím pre vnúčatá, jej čas jej nepatrí, žiadne aktivity nesmerujú len k nej samotnej. Dávajú ju do protikladu so západnou staršou ženou-turistkou, ktorá trávi svoj zvyšný čas objavovaním sveta. Bezpochyby sa tu tzv. Západniarka stáva rovnako stereotypnou figúrou ako „šede oděné strašidlo vláčející tašky potravin podél zdi paneláku“ (Šmejkalová 1998: 16), ktoré si vytvorila fantázia zmrazená studenou vojnou.

Obraz privilegovaných meštiačok sa prenáša aj na samotné Západné feministky, a to napríklad aj v Drakulićovej anekdotickom Liste zo Spojených štátov (1992), v ktorom ostro

20 Opät' Ghodsee (2004: 736) ponúka provokatívne zistenie, že štúdie sledujúce výlučne kategóriu rodu skresl'ovali údaje o transformácii tým, že predpokladali, že ženy budú jej obet’ami. Ukázalo sa však, že to, či zvládli systémový predchod a nakol'ko dokázali pre seba získat' výhody, bolo viac otázkou triedy než rodu a dokonca častokrát mali ženy výhodu nad mužmi vd’aka vyššej flexibilite, vzdelaniu a iným faktorom.

21 Najjasnejšie takáto rétorika zaznieva napr. v textoch Slavenky Drakulić, ktorá s obl’ubou tematizovala ošumelost' a trápnost' postsocialistických reálií oproti Západným scenériam reprezentovaným napríklad košíkom jahôd, ktorý možno na Manhattane zakúpit' aj uprostred treskúcej newyorskej zimy - podobnost's rozprávkou o Dvanástich mesiačikoch je možno náhodná, no dalo by sa hovorit' o spoliehaní sa na kultúrne mémy. 
odpovedá na požiadavku americkej akademičky, aby prispela do antológie o postsocialistických ženách. Drakulić si predstavuje autorku listu takto:

[Americká akademička] sa ma pýta na diskusiu o esencializme v Juhoslávii sediac vo svojej pracovni na univerzite, za chrbtom polička plná kníh o marxizme, feminizme alebo kritickej teórii. Viem si ju dobre predstavit': má na sebe obnosené džínsy a módne tričko, zastrihnuté čierne vlasy, vyzerá mladšie, než naozaj je (aerobik a makrobiotická strava), sedí za počítačom a t’uká tento list, tieto slová, ktoré - ked' ich čítam v záhrebskej električke o desat' dní neskôr - znejú tak absurdne, že sa pri nich musím smiat', akoby som čítala nejaké dobré správy. (Drakulić 1992: 127 [kurzíva v origináli])

Jej rozčúlenie vychádza jednak z uvedomenia si, že napriek súnáležitosti s novou analytickou kategóriou Východných žien (ktorej hovorkyňou by mala byt'), v procese formulovania poznania o tejto skupine má len vedl’ajšiu rolu. „Strávila pár týždňov v Berlíne, ' pomyslela som si čítajúc [list] v električke, ,a zrazu robí antológiu!'Aké je to pre ňu l'ahké; dokonca už má vydavatel'a“" (Drakulić 1992: 126).

Americká akademička je znázornená ako chic žena, ktorá má svoju izbu (v zmysle Woolfovej vlastnej izby ako priestoru a času na štúdium a tvorivú prácu), má kontrolu nad svojím vzhl'adom - je to možno aj práca, ktorá ju udržuje sviežu a v pohybe, podobne ako cvičenie a zdravá strava (opät' sa tu v istom zmysle opakuje motív, že feminizmus je prácou na sebe, napomáha uvedomelej individualizácii žien). Kým táto Západná žena sa vol'ne pohybuje po svete a zakresl'uje neprebádané miesta na znalostnú mapu, určuje im mená (kategória „Východné ženy“) a rozdel’uje úlohy lokálnym výskumným silám, Drakulić nezostáva iné, než jedovat' sa v mestskej doprave, možno na ceste medzi úradom a domácnost'ou, v šatách z nepredajných kolekcií, ktoré putovali na Východ, a príliš výrazne našminkovaná (ako ju upozornili jej západné sestry).

Obraz chorvátskej esejistky a spisovatel'ky som dotvorila na základe jej d’alších esejí (Drakulić 1992, 1993, 1996), no mohol by nám napomôct' vcítit' sa do naznačenej kritickej pozície raných feministiek, ktoré prijali kategóriu rodu/genderu a pracovali s ňou, identitifikovali sa na jej základe. Tak, ako spomínané tzv. farebné ženy alebo teoretičky postkolonializmu reagujúce na „export feminizmu do nezápadního světa prostřednictvím rozvojové pomoci a post-koloniální demokratizace“ (Kodíčková 2002: 74 [kurzíva v origináli]), ani tzv. Východné feministky nemohli celkom uniknút' kategóriam, ktoré predostreli tzv. Západné feministky. Mohli zaujat' rozličné postoje od odmietnutia, skepse a kritiky až k nadšenej sebaidentifikácii (vid' Chřibková a kol. 1999; Cviková a Juráňová 2009a).

Nemali však motiváciu podobnú postkoloniálnej kritike, aby sa pokúšali odrezat' od kategórií, ktoré sú na ne uvalené (vo význame delinking ako spôsobu vyviaznutia z diskurzívnej kolonizácie [Mignolo 2007]). Častokrát naopak vnímali kategóriu rodu ako zmysluplný spôsob sebaidentifikácie a kritického postoja voči diskurzom nacionalizmu, divokému kapitalizmu či pozostatkom socializmu (Cviková a Juráňová 2009a: 17).

Praktikovanie feminizmu - študovanie textov, zúčastňovanie sa konferencií, organizovanie prednášok a workshopov, uchádzanie sa o grantovú podporu, budovanie knižníc či stavanie sylabov, komponovanie učebníc a mapovanie ženských hlasov, kampane proti násiliu na ženách či materské centrá - to všetko muselo byt' bezpochyby pocitované ako skutočná 
účast' na budovaní občianskej (no nie nutne spravodlivejšej) spoločnosti, aktívna výstavba ženského politického subjektu, sietí solidarity aj sebarozvoj. Síce sa k tomuto subjektu ženy nehlásili masovo, no určitej skupine idea zdiel’aného ženstva ponúkla umeleckú inšpiráciu, intelektuálne zdroje alebo/a prácu posvätenú väčším naratívom.

Cesta prenosu ideí od elít $\mathrm{k}$ širšiemu povedomiu tak zodpovedá forme vytvárania občianskej spoločnosti v krajinách strednej a východnej Európy. Napríklad podla Ioany Cîrstocea (2009: 2) rumunské intelektuálne kruhy napriek nezáujmu šišej verejnosti formulovali potrebu feministických myšlienok ako „súčasti širšej filozofie post-komunistickej transformácie videnej ako moment historickej modernizácie a ako možnosti reorganizovat' spoločnost' a spochybnit' tak rodové vzt’ahy a nanovo premysliet' spoločenské úlohy žien“.

Politický subjekt sa nevynára zdola, aby naliehal a vyjednával svoje práva a menil pravidlá hry, ale je prenášaný osvetou, naučený, osvojený a stotožňovaný so zavádzaním nových poriadkov. Takáto cesta zhora nadol nie je v hrubých rysoch nepodobná socialistickej emancipácii (samotné porovnanie ju nijako nezbavuje legitimity). Žiada sa tu možno dôslednejšie preskúmanie týchto emancipačných programov nie v zvyčajnej nezmieritel’nej opozícii, ale v komparatívnom rámci.

\section{Záverom}

Biele miesto, ktoré som sa snažila $\mathrm{v}$ tomto článku diskutovat’ na základe dvoch identifikovaných kritických línií, som symbolicky nazvala čakaním na „našu“ Mohanty. Figúra feministickej postkoloniálnej teoretičky zosobňuje túžbu kritických feministických hlasov v regióne CEE po svojbytnom konceptuálnom aparáte a originálnom príspevku, ktorý by otriasol feministickou teóriou tak, ako sa to $\mathrm{v} 80$. rokoch podarilo práve postkoloniálnym teoretičkám.

Zároveň takéto prianie vždy a znovu naráža na vysvetlenia, prečo rané postsocialistické feministky napriek nezanedbatel'nému kritickému potenciálu nemohli túto objednávku vyplnit'. Kodíčková a Kampichler používajú vo svojich kritikách raného postsocialistického feminizmu (so zameraním na Česko v kontexte CEE) práve Mohanty ako kritické východisko, cez ktoré pomenúvajú neduhy a nemožnosti vtedajších teoretických prístupov.

Snažila som sa pokračovat' $v$ ich kritickej línii a zároveň ju napojit' na feministické hl'adiská mapujúce širší kontext prenosu a inštitucionalizácie feministických myšlienok v regióne CEE. Jednak som chcela výrazne upozornit' na transformačné ideológie, ktoré sa otlačili v prácach raných feministiek, ale zároveň som nástojila na prístupe, ktorý by nezmazal ich energiu a úsilie pod tiažou novopoložených hegemónnych štruktúr a tendencií.

Zároveň som ponúkla niekol'ko možných zdrojov d’alšieho výskumného záujmu. V náväznosti na Mahmood, Watson a Loutfi totiž verím, že skúmanie problematiky prítomnosti tzv. Západného feminizmu v postsocialistickom priestore potenciálne otvára sériu nepohodlných, no rozhodne podnetných otázok o politickej identite/identitách feministického projektu. Problematický nie je samotný projekt, ale zneviditel'ňovanie určitých „,samozrejmostí“, na ktorých stavia vo svojich zjednodušených a preskriptívnych formách. 


\section{Literatúra}

ABU-LUGHOD, Lila. The romance of resistance: Tracing transformations of power through Bedoiun women. American Ethnologist, 1990, roč. 17, č. 1, s. 41-55. ISSN 1548-1425.

ABU-LUGHOD, Lila. Do Muslim Women Really Need Saving? [online]. 2002 [cit. 16. 1. 2014]. Dostupné z: http://www.smi.uib.no/seminars/Pensum/Abu-Lughod.pdf.

BLAGOJEVIĆ, Marina. Migrating Gender Scholar: Epistemic and Other Consequences. Migrating Feminisms Conference. 26.-27. ledna 2006, Budapest.

BUDEN, Boris. Konec postkomunismu: Od společnosti bez naděje k naději bez společnosti. Praha: Rybka publishers, 2013. ISBN 9788087067703.

CERWONKA, Allaine. Higher Education 'Reform', Hegemony, and Neo-Cold War Ideology: Lessons from Eastern Europe. Cultural Studies, 2009, roč. 23, č. 2-3, s. 720-735. ISSN 0950-2386.

CÎRSTOCEA, Ioana. Sociology of a new field of knowledge: Gender studies in postcommunist Eastern Europe. GSPE Working Papers [online]. 2009 [cit. 16. 1. 2014]. Dostupné z: http://prisme. u-strasbg.fr/workingpapers/WPCirstocea.pdf.

CVIKOVÁ, Jana a Jana JURÁŇOVÁ. Feminisms for Beginners. Aspects of the Origins of Gender Discourse in Slovakia. In Gender Issues 2009: Gender Equality Discourse in Times of Transformation, 1989-2009. The Czech Republic, Poland, Slovakia and Ukraine. Warsaw: Heinrich Böll Foundation Regional Office, 2009a, s. 79-127. ISBN 978-83-61340-48-5.

CVIKOVÁ, Jana a Jana JURÁŇOVÁ. Feminizmy pre začiatočníčky: Aspekty zrodu rodového diskurzu na Slovensku. Bratislava: Aspekt, 2009b. ISBN 9788085549850.

DRAKULIĆ, Slavenka. A Letter from the United States - The Critical Theory Approach. In DRAKULIĆ, Slavenka (ed.). How we survived Communism and even laughed. London: Vintage Books, 1992, s. 123-132. ISBN 0099265710.

DRAKULIĆ, Slavenka. The Balkan express: fragments from the other side of war. London: Hutchinson, 1993. ISBN 0091775272.

DRAKULIĆ, Slavenka. Café Europa: life after communism. London: Abacus, 1996. ISBN 0349107297.

EINHORN, Barbara. Cinderella goes to market: Citizenship, gender and women's movements in East Central Europe. New York: Verso, 1993. ISBN 0860916154.

FODOR, Éva. Gender in Transition: Unemployment in Hungary, Poland and Slovakia. East European Politics and Societies, 1997, roč. 11, č. 3, s. 470-500. ISSN 0888-3254.

FRASER, Nancy. Feminism, capitalism and the cunning of history. New Left Review, 2009, roč. 56, č. 3-4, s. 97-117. ISSN 0028-6060.

FUNK, Nanette. Introduction. In FUNK, Nanette a Magda MUELLER (eds.). Gender Politics and Post-Communism: Reflections from Eastern Europe and the Former Soviet Union. New York: Routledge, 1993, s. 1-14. ISBN 0415904781.

GAL, Susan a Gail KLIGMAN. The politics of gender after socialism: A comparative-historical essay. Princeton (NJ): Princeton University Press, 2000. ISBN 0691048932.

GANDHI, Leela. Postcolonial theory: A critical introduction. New York: Columbia University Press, 1998. ISBN 0231112726.

Gender Issues 2009: Gender Equality Discourse in Times of Transformation, 1989-2009. The Czech Republic, Poland, Slovakia and Ukraine. 2009. Warsaw: Heinrich Böll Foundation Regional Office. ISBN 978-83-61340-48-5.

GHODSEE, Kristen. Feminism-by-Design: Emerging Capitalisms, Cultural Feminism, and Women's Nongovernmental Organizations in Postsocialist Eastern Europe. Signs, 2004, roč. 29, č. 3, s. 727-753. ISSN 0097-9740.

HAVELKOVÁ, Hana. A few prefeminist thoughts. In FUNK, Nanette a Magda MUELLER (eds.). Gender Politics and Post-Communism: Reflections from Eastern Europe and the Former Soviet Union. New York: Routledge, 1993, s. 62-73. ISBN 0415904781. 
HAVELKOVÁ, Hana. Mezi pragmatismem a ideologií - obrana socialisticky emancipovaného ženství. In OATES-INDRUCHOVÁ, Libora (ed.). Tvrdošíinost myšlenky: Od feministické kriminologie k teorii genderu. Praha: Sociologické nakladatelství, 2011, s. 87-101. ISBN 8074190439.

HAVELKOVÁ, Hana a Libora OATES-INDRUCHOVÁ. The Politics of gender culture under state socialism: An expropriated voice. London: Routledge, 2014. ISBN 978-0-415-72083-0.

HEWITT, Nancy A. Feminist frequencies: Regenerating the wave metaphor. Feminist Studies, 2012, roč. 38, č. 3, s. 658-680. ISSN 2153-3873.

HOLMES, Leslie. Post-communism: An Introduction. Cambridge: Polity Press, 1997. ISBN 074561311X.

CHŘIBKOVÁ, Marie, Josef CHUCHMA a Eva KLIMENTOVÁ (eds.). Nové čteni světa: Feminismus devadesátých let českýma očima. Praha: One Woman Press, 1999. ISBN 809024436X.

JAQUETTE, Jane a Sharon WOLCHIK. Women and Democracy: Latin America and Central and Eastern Europe. Baltimore: Johns Hopkins University Press, 1998. ISBN 0801858372.

KAMPICHLER, Martina. Za hranice feministických diskusí mezi Východem a Západem. Gender, rovné př́ležitosti, výzkum, 2012, roč. 13, č. 2, s. 4-17. ISSN 1213-0028.

KARAM, Azza M. Islamisms and feminism in Egypt: Three generations of women's perspectives. In BACHETTA, Paola a Margaret POWER (eds.). Right-wing women: From conservatives to extremists around the world. New York: Routledge, 2002, s. 225-244. ISBN 0415927781.

KEPPLOVÁ, Zuzana. Po stopách „marxizmu v sukni“: Ku genealógii rodového diskurzu u nás a k jeho antifeministickým protihlasom. Glosolália, 2013, roč. 2, č. 4, s. 15-20. ISSN 1338-7146.

KICZKOVÁ, Zuzana a Etela FARKAŠOVÁ. The emancipation of women: A concept that failed. In FUNK, Nanette a Magda MUELLER (eds.). Gender Politics and Post-Communism: Reflections from Eastern Europe and the Former Soviet Union. New York: Routledge, 1993, s. 84-94. ISBN 0415904781.

KIOSSEV, Alexander. Notes on self-colonizing cultures. In PEJIĆ, Bojana a David ELLIOT (eds.). After the Wall: Art and Culture in Post-Communist Europe. Stockholm: Moderna Museet, 1999, s. 114-177. ISBN 9171006060.

KIOSSEV, Alexander. The oxymoron of normality [online]. 2008 [cit. 16. 3. 2014]. Dostupné z: http:// www.eurozine.com/articles/2008-01-04-kiossev-en.html.

KODÍČKOVÁ, Tereza. Co je nám do třetího světa aneb zpráva o analýze českých akademických genderových textů. Sborník prací Fakulty sociálních studii MU. Sociální studia, 2002, č. 7, s. 69-87. ISSN 1214-813X.

KOMÁREK, Stanislav. Muž jako evoluční inovace: Eseje o maskulinitě, její etologii, životnich strategiích a proměnách. Praha: Academia, 2012. ISBN 134108.

LOUTFI, Anna. Politics and Hegemony in the Historiography of Women's Movements (Nineteenth and Twentieth Centuries): A Call for New Debates. In GEHMACHER, Johanna a Natascha VITTORELLI (eds.). Wie Frauenbewegung geschrieben wird. Historiographie, Dokumentation, Stellungnahmen, Bibliographien. Vienna: Löcker Verlag, 2009, s. 81-102. ISBN 978-3-85409-521-7.

MAHMOOD, Saba. Politics of piety: The islamic revival and the feminist subject. Princeton: Princeton University Press, 2005. ISBN 0691086958.

MIGNOLO, Walter D. Delinking: The rhetoric of modernity, the logic of coloniality and the grammar of de-coloniality. Cultural Studies. 2007, roč. 21, č. 2, s. 449-514. ISSN 0950-2386.

MOHANTY, Chandra T. Under western eyes: Feminist scholarship and colonial discourses. boundary 2, 1984, roč. 12/13, č. 3/1, s. 333-358. ISSN 0190-3659. Dostupné z: http://blog.lib.umn. edu/raim0007/RaeSpot/under\%20wstrn\%20eyes.pdf.

MOHANTY, Chandra T. Feminism without borders: decolonizing theory, practicing solidarity. Durham: Duke University Press, 2003. ISBN 0822330210.

NYKLOVÁ, Blanka. Krajinou českého feminismu. Gender, rovné přiležitosti, výzkum, 2013, roč. 14, č. 1, s. 52-63. ISSN 1213-0028. 
OFFEN, Karen. How and why the analogy of marriage with slavery provided the springboard for women's rights in France, 1640-1848. In SKLAR, Kathryn K. a James B. STEWART (eds.). Women's rights and transatlantic antislavery in the era of emancipation. New Haven: Yale University Press, 2007, s. 57-81. ISBN 9780300115932.

SLAVOVA, Kornelia. Looking at Western feminisms through the double lens of Eastern Europe and the Third World. In LUKIĆ, Jasmina, Joanna REGULSKA a Darja ZAVIRŠEK (eds.). Women and Citizenship in Central and Eastern Europe. Aldershot: Ashgate, 2006, s. 245-265. ISBN 9780754646624.

SPIVAK, Gayatri C. Can the subaltern speak? In NELSON, Cary a Lawrence GROSSBERG (eds.). Marxism and the Interpretation of Culture. London: Macmillan, 1988, s. 271-314. ISBN 0-252-01401-4.

STARK, David. Path Dependence and Privatization Strategies in East Central Europe. East European Politics and Societies, 1992, roč. 6, č. 1, s. 17-54. ISSN 0888-3254.

ŠIKLOVÁ, Jiřina. Are women in Central and Eastern Europe conservative? In FUNK, Nanette a Magda MUELLER (eds.). Gender Politics and Post-Communism: Reflections from Eastern Europe and the Former Soviet Union. New York: Routledge, 1993, s. 74-83. ISBN 0415904781.

ŠIKLOVÁ, Jiřina. McDonald's, Terminators, Coca Cola Ads - and Feminism? Imports from the West. In RENNE, Tanya (ed.). Ana's Land: Sisterhood in Eastern Europe. Boulder (CO): Westview Press, 1997, s. 76-81. ISBN 0813328314.

ŠMAUSOVÁ, Gerlinda. Proti tvrdošíjné představě o ontické povaze gender a pohlaví. Sborník prací Fakulty sociálních studií MU. Sociální studia, 2002, č. 7, s. 15-27. ISSN 1214-813X.

ŠMAUSOVÁ, Gerlinda. Emancipace, socialismus a feminismus. In OATES-INDRUCHOVÁ, Libora (ed.). Tvrdošijnost myšlenky: Od feministické kriminologie k teorii genderu. Praha: Sociologické nakladatelství, 2011, s. 195-206. ISBN 8074190439.

ŠMEJKALOVÁ, Jiřina. On the Road: Smuggling Feminism Across the Post-Iron Curtain. In FEISCHMIDT, Margit, Enikö MAGYARI-VINCZE a Violetta ZENTAI (eds.). Women and Men in East European Transition. Cluj-Napoca: Editura Fundatiei Pentru Studii Europene, 1997, s. 25-32. ISBN 9739826849.

ŠMEJKALOVÁ, Jiřina. Strašidlo feminismu v českém „porevolučním“ tisku: úvaha, doufejme, historická. In HAVELKOVÁ, Hana a Mirek VODRÁŽKA (eds.). Žena a muž v médiích. Praha: Nadace Gender Studies, 1998, s. 16-18. ISBN 80-902367-2-3.

TODOROVA, Maria. Imagining the Balkans. New York: Oxford University Press, 1997. ISBN 0195387864.

VASILESCU, Mircea. Normality or normalities? From one transition to the next. Eurozine [online]. 2008 [cit. 16. 3. 2014]. Dostupné z: http://www.eurozine.com/articles/2007-10-04-vasilescu-en.html.

WAGNEROVÁ, Alena. České ženy na cestě od reálného socialismu k reálnému kapitalismu. In CHŘIBKOVÁ, Marie, Josef CHUCHMA a Eva Klimentová (eds.). Nové čteni světa: Feminismus devadesátých let českýma očima. Praha: One Woman Press, 1999, s. 80-90. ISBN 809024436X.

WATSON, Peggy. Eastern Europes's silent revolution: gender. Sociology, 1993, roč. 27, č. 3, s. 471-487. ISSN 0038-0385.

WATSON, Peggy. Rethinking transition, globalism, gender and class. International Feminist Journal of Politics, 2000, roč. 2, č. 2, s. 186-213. ISSN 1461-6742.

WÖHRER, Veronika. The tradition of literature within slovak women's organisations and gender studies. [online]. TRANS. Internet-Zeitschrift für Kulturwissenschaften, 2005, č. 14. ISSN 1560-182X. [cit. 16. 3. 2014]. Dostupné z: http://www.inst.at/trans/14Nr/woehrer14.htm.

YURCHAK, Alexei. Everything was forever, until it was no more: the last Soviet generation. Princeton (NJ): Princeton University Press, 2006. ISBN 0691121176. 
ZEZULOVÁ, Jana. Feministické výskumné programy v koncepcii Sandry Harding. In KICZKOVÁ Zuzana a Mariana SZAPUOVÁ (eds.). Rodové štúdiá: Súčasné diskusie, problémy a perspektívy. Bratislava: Centrum rodových štúdií, Filozofická fakulta Univerzity Komenského, 2011, s. 350-362. ISBN 978-80-223-2934-7.

ZIMMERMANN, Susan. The Institutionalization of Women and Gender Studies in Higher Education in Central and Eastern Europe and the Former Soviet Union: Asymmetric Politics and the Regional-Transnational Configuration. East-Central Europe, 2007, roč. 33, č. 1-2, s. 131-160. ISSN 0094-3037.

\section{Autorka}

Zuzana Kepplová je postdoktorandkou na Fakultě sociálních studií Masarykovy univerzity v Brně, publicistkou a autorkou. Vyučuje kurzy na pomedzí rodových a kulturálnych štúdií. Zaujíma ju, ako pojmy subkultúr, mládeže a populárnej kultúry formovala studená vojna a akú úlohu zohrali počas transformácie. Zaoberá sa tiež miestom tzv. nových disciplín vo formovaní spoločenských diskurzov a znalostných kánonov.

Kontakt: kepplova@mail.muni.cz 